\title{
Occurrence of Methane in Groundwater of South-Central New York State, 2012- Systematic Evaluation of a Glaciated Region by Hydrogeologic Setting
}

Scientific Investigations Report 2013-5190 
Cover photo. View looking west across the valley of Catatonk Creek near Candor, New York. 


\section{Occurrence of Methane in Groundwater of South-Central New York State, 2012- Systematic Evaluation of a Glaciated Region by Hydrogeologic Setting}

By Paul M. Heisig and Tia-Marie Scott

Scientific Investigations Report 2013-5190 


\title{
U.S. Department of the Interior SALLY JEWELL, Secretary
}

\section{U.S. Geological Survey Suzette M. Kimball, Acting Director}

\author{
U.S. Geological Survey, Reston, Virginia: 2013
}

For more information on the USGS - the Federal source for science about the Earth, its natural and living resources, natural hazards, and the environment, visit http://www.usgs.gov or call 1-888-ASK-USGS.

For an overview of USGS information products, including maps, imagery, and publications, visit http://www.usgs.gov/pubprod

To order this and other USGS information products, visit http://store.usgs.gov

Any use of trade, firm, or product names is for descriptive purposes only and does not imply endorsement by the U.S. Government.

Although this information product, for the most part, is in the public domain, it also may contain copyrighted materials as noted in the text. Permission to reproduce copyrighted items must be secured from the copyright owner.

Suggested citation:

Heisig, P.M., and Scott, Tia-Marie, 2013, Occurrence of methane in groundwater of south-central New York State, 2012 - Systematic evaluation of a glaciated region by hydrogeologic setting: U.S. Geological Survey Scientific Investigations Report 2013-5190, 32 p., http://dx.doi.org/10.3133/sir20135190. 


\section{Acknowledgments}

The authors extend thanks and appreciation to all well owners who took time to fill out well surveys and to those who gave permission and facilitated sampling of their wells, which was critical to the study. Thanks are also extended to U.S. Geological Survey personnel whose work supported the study. Elizabeth Nystrom assisted with sampling and sampling equipment in the field, including the field measurement of methane. Richard Reynolds and Carolyn Van Alstyne also assisted with field sampling, and Patrick Phillips prepared statistical and quality-assurance analyses. Martyn Smith and Douglas Freehafer provided geographic information system support that included processing of lidar imagery, and generation and processing of stream network and topographic information that facilitated the definition of valley areas. The authors gratefully acknowledge funding from the New York State Energy Research and Development Authority. 
THIS PAGE INTENTIONALLY LEFT BLANK 


\section{Contents}

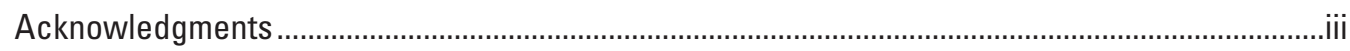

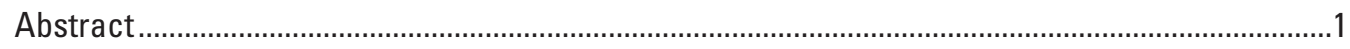

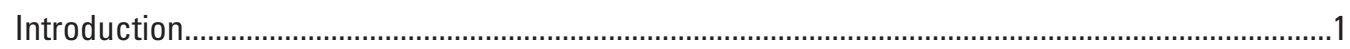

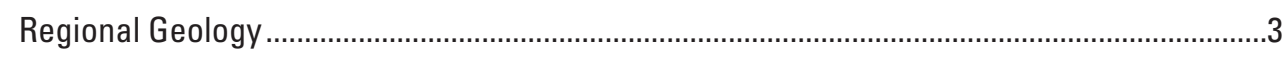

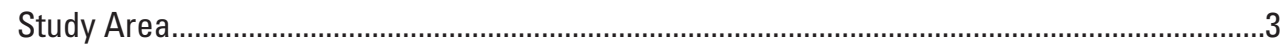

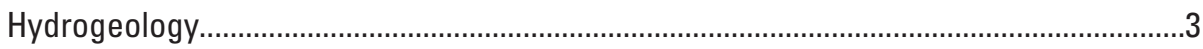

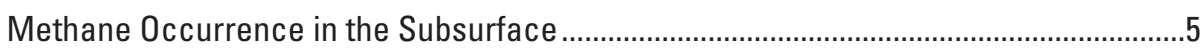

Methane in Groundwater .......................................................................................

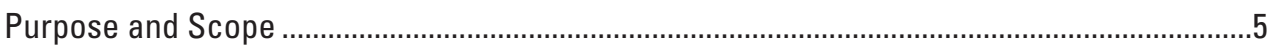

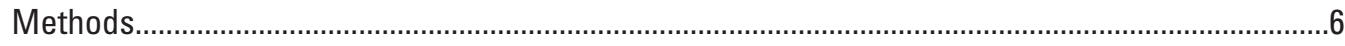

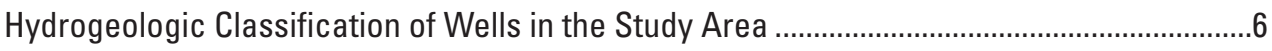

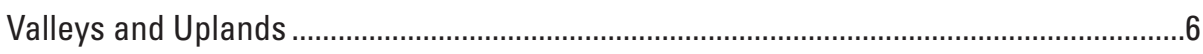

Confined Conditions ...........................................................................................................

Additional Classification of Valley Settings ....................................................................

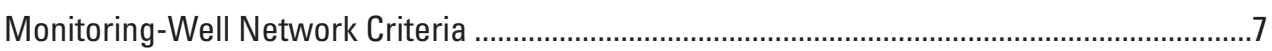

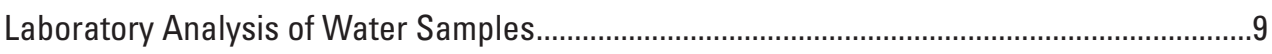

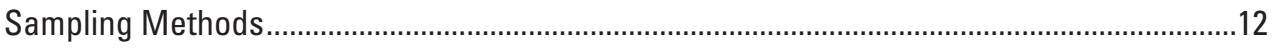

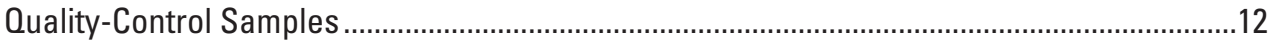

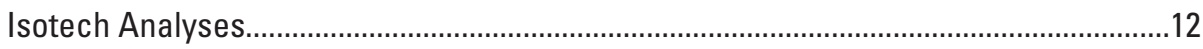

Reston Chlorofluorocarbon Laboratory Analyses .......................................................13

Comparison of Isotech and Reston Chlorofluorocarbon Laboratory Analyses...............13

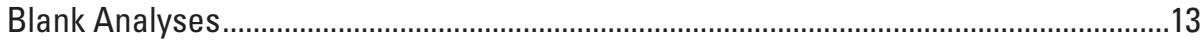

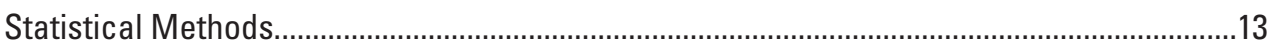

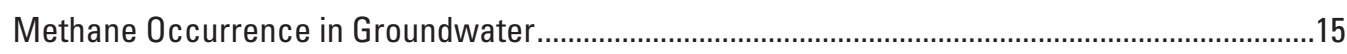

Methane Concentrations and Hydrogeologic Setting .......................................................

Methane Concentrations and Field-Characteristic Measurements .......................................15

Methane Concentrations and Well Completion.................................................................19

Use of Isotopic Data to Assess Methane Source(s) ..............................................................19

Conceptual Model of Methane Occurrence in South-Central New York..........................................21

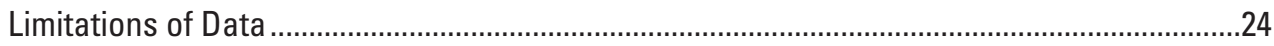

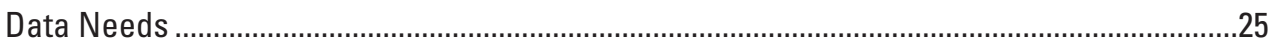

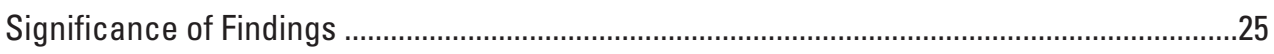

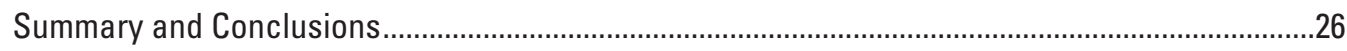

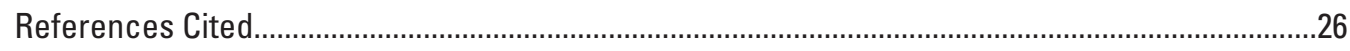

Appendix 1. Description of Selected Wells in South-Central New York, Including

Hydrogeologic Setting Class, Well Completion Information, Aquifer, and Bedrock

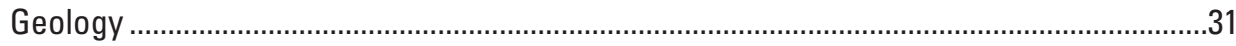

Appendix 2. Constituents Analyzed in, and Laboratory Methods Used for, Water Samples Collected from Selected Wells in South-Central New York ...............................................31

Appendix 3. Results of Analyses for Dissolved Gases in Water Samples Collected from Selected Water Wells in South-Central New York, 2012 (USGS CFC Laboratory)...............31 
Appendix 4. Results of Analyses for Physical Characteristics, and Dissolved Gases, Including Hydrocarbons and Hydrocarbon Isotopes in Water Samples Collected from

Wells in South-Central New York, 2012

Appendix 5. Methane Concentration in Relation to A, Confining Unit Thickness in Bedrock Wells in Valley Settings and $B$, Elevation of the Bottom of Confined Bedrock Valley Wells in South-Central New York

\section{Figures}

1. Generalized north-south section with bedrock formations in south-central New York

2. Map showing topographic elevations of the study area, south-central New York and vicinity.

3. Schematic diagram defining $A$, valley areas and $B-C$, widths: $A$, Valley linear extent defined in map view. $B$, Land area within 75 feet above the valley stream in small valleys with limited stratified glacial deposits. $C$, Large valleys with stratified glacial deposits are defined in a manner similar to that of small valleys, except where thick glacial deposits rise greater than 75 feet above the valley stream

4. Map showing locations of sampled water wells and former or existing gas wells with 1-mile buffers, and delineation of valley areas, in south-central New York and Pennsylvania

5. Bar graph showing ordered methane concentrations in samples from 65 wells in south-central New York, color-coded by hydrogeologic setting.

6. Graphs showing distribution of methane concentrations in samples from southcentral New York water wells, 2012, by hydrogeologic setting, for $A$, wells classified by topographic position and whether or not confined by glacial drift deposits and $B$, valley setting wells by well-completion in sand and gravel or bedrock

7. Graphs showing methane concentrations in relation to $\mathrm{pH}$ and specific conductance in valley and upland areas...

8. Boxplots showing distribution of characteristics of wells completed in bedrock hydrogeologic settings in south-central New York: $A$, Bedrock thickness penetrated by wells and $B$, elevations of the bottom of bedrock wells

9. Graph showing stable-isotopic composition of carbon (C) and hydrogen (deuterium; D) in methane $\left(\mathrm{CH}_{4}\right)$ in water-well samples from south-central New York

10. Conceptual diagram of thermogenic and microbial methane occurrence at water wells in south-central New York.

\section{Tables}

1. Hydrogeologic setting classification in the study area, south-central New York ............6

2. Summary of characteristics of sampled wells, by major hydrogeologic setting, south-central New York

3. Hydrogeologic classification of wells sampled, with each class color coded by percentage of samples with methane concentrations greater than or equal to: $A, 0.1$ milligram per liter, $B, 5$ milligrams per liter, and $C, 10$ milligrams per liter in south-central New York, 2012. 


\section{Conversion Factors, Datum, and Abbreviations}

Inch/Pound to SI

\begin{tabular}{lll}
\hline & Multiply & \multicolumn{1}{c}{ By } \\
\hline foot $(\mathrm{ft})$ & Length & To obtain \\
mile $(\mathrm{mi})$ & 0.3048 & meter $(\mathrm{m})$ \\
\hline & 1.609 & kilometer $(\mathrm{km})$ \\
\hline square mile $\left(\mathrm{mi}^{2}\right)$ & Area & \\
\hline & 2.590 & square kilometer $\left(\mathrm{km}^{2}\right)$ \\
\hline gallon $(\mathrm{gal})$ & Volume & \\
\hline
\end{tabular}

Temperature in degrees Celsius $\left({ }^{\circ} \mathrm{C}\right)$ may be converted to degrees Fahrenheit $\left({ }^{\circ} \mathrm{F}\right)$ as follows:

${ }^{\circ} \mathrm{F}=\left(1.8 x^{\circ} \mathrm{C}\right)+32$

Vertical coordinate information is referenced to the North American Vertical Datum of 1988 (NAVD 88).

Horizontal coordinate information is referenced to the North American Datum of 1983 (NAD 83).

Elevation, as used in this report, refers to distance above the vertical datum.

Specific conductance is given in microsiemens per centimeter at 25 degrees Celsius $(\mu \mathrm{S} / \mathrm{cm}$ at $\left.25^{\circ} \mathrm{C}\right)$.

Concentrations of chemical constituents in water are given either in milligrams per liter (mg/L) or micrograms per liter ( $\mu \mathrm{g} / \mathrm{L})$.

\section{Abbreviations}

CFC Chlorofluorocarbon

NWIS National Water Information System

NWQL National Water Quality Laboratory

USGS U.S. Geological Survey

VOC Volatile organic carbon 
THIS PAGE INTENTIONALLY LEFT BLANK 


\title{
Occurrence of Methane in Groundwater of South-Central New York State, 2012-Systematic Evaluation of a Glaciated Region by Hydrogeologic Setting
}

\author{
By Paul M. Heisig and Tia-Marie Scott
}

\section{Abstract}

A survey of methane in groundwater was undertaken to document methane occurrence on the basis hydrogeologic setting within a glaciated 1,810-square-mile area of southcentral New York along the Pennsylvania border. Sixty-six wells were sampled during the summer of 2012. All wells were at least 1 mile from any known gas well (active, exploratory, or abandoned). Results indicate strong positive and negative associations between hydrogeologic settings and methane occurrence. The hydrogeologic setting classes are based on topographic position (valley and upland), confinement or non-confinement of groundwater by glacial deposits, well completion in fractured bedrock or sand and gravel, and hydrogeologic subcategories. Only domestic wells and similar purposed supply wells with well-construction and $\log$ information were selected for classification. Field waterquality characteristics ( $\mathrm{pH}$, specific conductance, dissolved oxygen, and temperature) were measured at each well, and samples were collected and analyzed for dissolved gases, including methane and short-chain hydrocarbons. Carbon and hydrogen isotopic ratios of methane were measured in 21 samples that had at least 0.3 milligram per liter $(\mathrm{mg} / \mathrm{L})$ of methane.

Results of sampling indicate that occurrence of methane in groundwater of the region is common - greater than or equal to $0.001 \mathrm{mg} / \mathrm{L}$ in 78 percent of the groundwater samples. Concentrations of methane ranged over five orders of magnitude. Methane concentrations at which monitoring or mitigation are indicated (greater than or equal to $10 \mathrm{mg} / \mathrm{L}$ ) were measured in 15 percent of the samples. Methane concentrations greater than $0.1 \mathrm{mg} / \mathrm{L}$ were associated with specific hydrogeologic settings. Wells completed in bedrock within valleys and under confined groundwater conditions were most closely associated with the highest methane concentrations. Fifty-seven percent of valley wells had greater than or equal to $0.1 \mathrm{mg} / \mathrm{L}$ of methane, whereas only 10 percent of upland wells equaled or exceeded that concentration. Isotopic signatures differed between these groups as well. Methane in valley wells was predominantly thermogenic in origin, likely as a result of close vertical proximity to underlying methane-bearing saline groundwater and brine and possibly as a result of enhanced bedrock fracture permeability beneath valleys that provides an avenue for upward gas migration. Isotopic signatures of methane from four upland well samples indicated a microbial origin (carbon-dioxide reduction) with one sample possibly altered by microbial methane oxidation. Water samples from wells in a valley setting that indicate a mix of thermogenic and microbial methane reflect the close proximity of regional groundwater flow and underlying saline water and brine in valley areas. The microbial methane is likely produced by bacteria that utilize carbon dioxide or formational organic matter in highly reducing environments within the subregional groundwater flow system. This characterization of groundwater methane shows the importance of subsurface information (hydrogeology, well construction) in understanding methane occurrence and provides an initial conceptual framework that can be utilized in investigation of stray gas in south-central New York.

\section{Introduction}

The development of technology for high-volume hydraulic fracturing in horizontal gas and oil wells has made low-permeability black shale units within large areas of the northern Appalachian Basin (fig. 1) into areas attractive for natural-gas production. Widespread development of these resources, including drilling and extraction, could create the possibility of inadvertent introduction of natural gas (primarily methane) into drinking-water aquifers. This risk can be reduced if the casing and cementing of wells is properly designed and constructed. Historically (Williams, 2010), in these same areas, natural gas has been reported in some domestic well water; recent data on predrilling well-sampling of water wells in northeastern Pennsylvania confirm methane presence, but show a widespread distribution of methane at concentrations greater than or equal to 0.1 milligram per liter $(\mathrm{mg} / \mathrm{L})($ Molofsky and others, 2011). These findings indicate that, prior to shale-gas drilling in a region, a systematic understanding of the occurrence of dissolved methane in groundwater (specifically domestic wells) can be useful when methane concentrations in groundwater are of concern. 


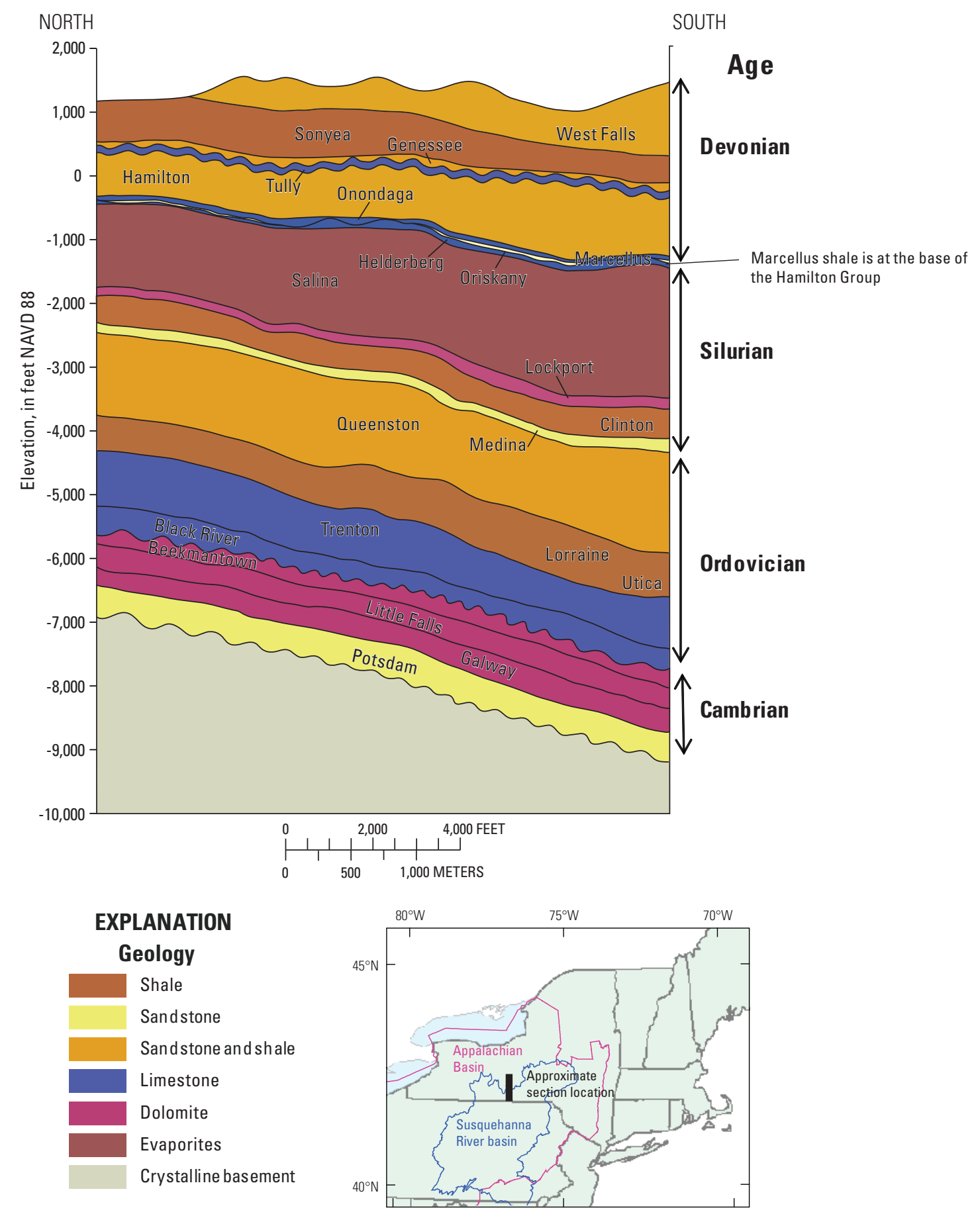

Figure 1. Generalized north-south section with bedrock formations in south-central New York (from Williams, 2010; modified from New York State Museum, 2009). 
Previous work on dissolved methane occurrence in groundwater in the region has focused primarily on the depth of water wells, the general bedrock unit tapped, and the topographic location. These depictions are unable to explain the wide range of groundwater chemical characteristics and methane concentrations observed partly because they lack information on the subsurface glacial geology and detailed information on well completion and well logs, such as the thickness of bedrock penetrated. This study, conducted in cooperation with the New York State Energy Research and Development Authority, addresses those needs by sampling wells with well-completion information that has been put into the larger context of hydrogeologic setting across the landscape. Hydrogeologic setting encompasses topographic position, the aquifer the well is completed in, bedrock type, glacial deposit types and thicknesses, and whether or not the groundwater is confined by glacial deposits.

\section{Regional Geology}

In south-central New York, a gently southward dipping sequence of sedimentary bedrock of Cambrian through Devonian age overlies Precambrian-age crystalline basement rock (fig. 1; Rickard and Fisher, 1970; Fisher and others, 1970). Natural gas has been reported in many of the sedimentary units (see fig. 2 in Kappel and Nystrom, 2012). With development of the high-volume hydraulic-fracturing technique, the organic-rich Marcellus Shale of Devonian age and Utica Shale of Ordovician age have become areas of interest in south-central New York State (Coleman and others, 2011; Kirschbaum and others, 2012). The Marcellus Shale is the shallower of the two units and is 4,000 to 5,000 feet (ft) below land surface, reaching its maximum depth in New York near the New York-Pennsylvania border; it becomes shallower northward 60 to 70 miles until it crops out at land surface (see Williams, 2010; fig. 1).

Bedrock is overlain by variable thicknesses of glacial deposits - drift - predominantly till in the uplands and stratified deposits in the valleys (Muller and Cadwell, 1986; Cadwell and Dineen, 1987; MacNish and Randall, 1982). Till is an unsorted mixture of sediments deposited by glaciers that is typically of low permeability with thicknesses ranging up to about $250 \mathrm{ft}$. Till is commonly thin or absent on hilltops or hillslopes facing north-northeast (the direction that faced advancing glaciers) and thickest on the opposite sides of hills (Coates, 1966). Stratified drift was deposited by glacial meltwaters and ranges from fine sand, silt, and clay deposited in proglacial lakes to sand and gravel in meltwater channels within and near melting ice or downvalley from the ice in southward-draining valleys.

\section{Study Area}

The study area (fig. 2) covers 1,810 square miles $\left(\mathrm{mi}^{2}\right)$ and encompasses all or part of five New York counties (Chemung, Tioga, Broome, Chenango, and Delaware) adjacent to northeastern Pennsylvania (fig. 2). This area is considered favorable for Marcellus Shale gas resources; estimated drilling depths to the base of the Marcellus Shale range from less than 3,000 ft in north-central Chemung County to more than 5,000 ft along the Pennsylvania border in southeastern Broome County (Wrightstone, 2009). The study area is underlain predominantly by clastic sedimentary sequences (sandstone, siltstone, shale, with only minor carbonate rocks) of the West Falls and Sonyea Groups (fig. 1). The northern boundary of the study area is defined as either the northern mapped extent of the Sonyea Group or the northern boundary of each county in the study area, whichever is farthest south. This boundary was selected to avoid bedrock containing significant carbonate units, such as the Tully Limestone, which would have introduced water-chemistry variations associated with dissolution of carbonate rock. The eastern boundary is defined as being just west of the Cannonsville Reservoir, which provides part of New York City's water supply. Highvolume hydraulic-fracturing gas wells will not be permitted within the New York City watershed per the New York State Department of Environmental Conservation's (NYSDEC) September 2011 Draft Supplemental Generic Environmental Impact Statement, Chapter 3-Section 3.2.4 Prohibited Locations (http://www.dec.ny.gov/energy/75370.html).

\section{Hydrogeology}

Hydrogeology of the study area includes fresh groundwater flow systems in the stratified drift in large valleys and in fractured bedrock throughout the area. Freshwater flow systems overlie nearly stagnant saline water or brine in the northern Appalachian Basin (Poth, 1962; Williams, 2010; Heisig, 1999; Williams and others, 1998; Schiner and Gallaher, 1979; Wunsch, 1993; Hopkins, 1966). The lack of appreciable flow of the saline water and brine has been attributed to lack of a driving force for flow, its high density and occurrence beneath the freshwater flow system, its local points of discharge (Poth, 1962), and the general decrease in fracture permeability with depth. Active fresh groundwater flow systems are generally viewed as having flushed out pre-existing saline water and brine (Poth, 1962, 1963). The position of the freshwater/saline-water (or brine) transition in valley and upland areas, however, is poorly defined because of limited data and uncertainties introduced by flow in wellbores. In larger valleys, the depth to saline water has been reported from less than $100 \mathrm{ft}$ to a few hundred feet below the valley floor (Wunsch, 1993; Heisig, 1999; Poth, 1963; Williams, 2010). A recent well drilled within the Susquehanna River valley at Binghamton, N.Y., penetrated a saline water-bearing fracture at $320 \mathrm{ft}$ below land surface and $274 \mathrm{ft}$ into bedrock [Well BM 504, U.S. Geological Survey (USGS) National Water Information System (NWIS) database; http://waterdata. usgs.gov/nwis]. Depth to saline water or brine in upland areas is largely undefined. The transition between freshwater and saline water or brine in fractured bedrock may be sharpa fracture containing water with high salinity (J.H. Williams, 

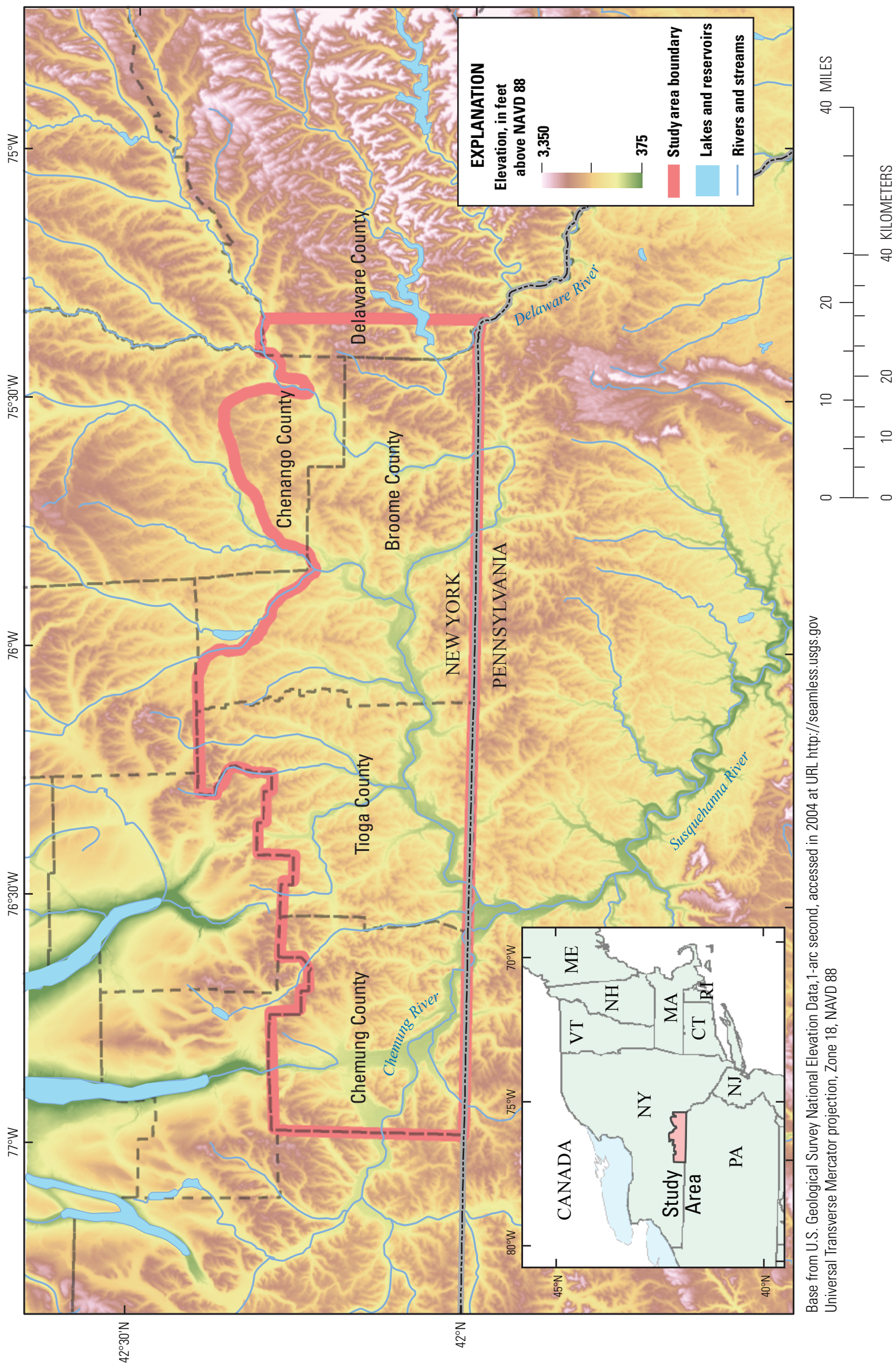

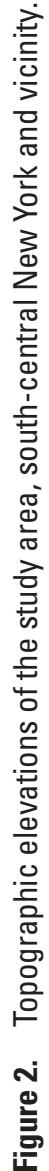


U.S. Geological Survey, oral commun., 2012; Heisig and Knutson, 1997)—or gradual (Hopkins, 1966).

MacNish and Randall (1982) conceptualize and classify the hydrogeologic framework of stratified-drift aquifers across the Susquehanna River Basin in New York, which encompasses most of the study area, and Randall (2001) provides a comprehensive framework for stratified-drift aquifer assessment with descriptions of conditions, by region, for the glaciated northeastern United States. More detailed stratified-drift aquifer mapping has been undertaken in the study area since the early 1980s (for example, Holocek and others, 1982; Miller and others, 1982; Reynolds and Garry, 1990; Reynolds, 2003; Miller and Pitman, 2012; and Heisig, 2012). In general, groundwater flow in valleys moves from the valley walls toward the stream or river. This flow is most rapid in shallow unconfined permeable deposits in hydraulic connection with the stream and slowest in deeper valley sand and gravel or bedrock, particularly if there is an intervening confining unit.

The primary source of groundwater to wells in upland areas is fractured bedrock (for example, Heisig, 2012). Few hydrogeologic studies in the Appalachian Basin in New York have focused on upland-hillside flow systems. Heisig (1999) conceptualizes groundwater flow in hillsides in the northern Catskill Mountains from geophysical logs and groundwaterlevel measurements from a small number of hillside wells (Heisig and Knutson, 1997) and from detailed hillside studies in the Eastern Kentucky Coalfield (Kipp and others, 1983; Minns, 1993; Wunsch, 1993).

\section{Methane Occurrence in the Subsurface}

In areas underlain by gas-bearing bedrock, widespread upward migration (microseepage) of hydrocarbons to overlying groundwater and soils has been recognized (Chafin, 1994; Direct Geochemical, 2004). In western New York, anomalously high methane concentrations and hydrocarbon ratios (ethane/ethene, methane/ethane) in soil gas have been used to identify faults and as a prospecting tool for natural-gas reservoirs (Fountain and Jacobi, 2000; Direct Geochemical, 2004). These studies show regional hydrocarbon microseepage with seepage rates locally enhanced by faulting and fracturing. Upward seepage can be curtailed by capping or confining units (Chafin, 1994), which may include bedrock strata in which fractures are mostly closed and, in glaciated areas, overlying glacial-drift deposits of low permeability.

\section{Methane in Groundwater}

Pre-1990 data on methane in groundwater from southcentral New York are limited and qualitative, collected from homeowners during water-well inventories (for example, Randall, 1972). Williams (2010) compiled gas and saltwater occurrence data from these pre-1990 studies and from gas-well logs from the Empire State Oil and Gas Information System database (http://esogis.nysm.nysed.gov/). The occurrence of gas and saltwater was most common in valley areas, but most of the inventoried water wells were in valleys so the extent of gas and saltwater in upland areas was not well characterized during this period.

Analyses of dissolved gas in groundwater that include methane analysis became more common in the 1990s because dissolved gas concentrations were required for chlorofluorocarbon groundwater age-dating techniques (Kappel and Nystrom, 2012). Interest in methane related to shale-gas resource development resulted in the addition (in 2009) of dissolved gas to the suite of analytes analyzed in the groundwater samples annually collected by USGS in cooperation with the New York State Department of Environmental Conservation (Nystrom, 2012; see http://ny.water.usgs.gov/projects/305b/). Kappel and Nystrom (2012) compiled datasets of results of analyses for water samples from New York and presented a map and statistics of concentrations by geologic formation. Methane occurrence at low concentrations $(0.001$ to $1 \mathrm{mg} / \mathrm{L})$ is widespread, but higher concentrations are largely present in bedrock wells completed in sedimentary bedrock.

Recent studies of methane in groundwater associated with Marcellus Shale gas drilling include Osborn and others (2011) and Molofsky and others $(2011,2013)$. Osborn and others (2011) sampled 51 bedrock wells in northeastern Pennsylvania and 9 in Otsego County, New York, and measured dissolved gas concentrations of methane and higher-chain hydrocarbons, and carbon and hydrogen isotope ratios of methane. Well depth, bedrock formation, and proximity to active gas wells were recorded. Water collected from wells within 1 kilometer $(\mathrm{km})$ of active gas wells (some within an area of known methane contamination) accounted for all but one methane concentration greater than $10 \mathrm{mg} / \mathrm{L}$. Isotopic signatures of methane indicated a thermogenic origin (interpreted as consistent with Middle Devonian or older strata including the Marcellus Shale) for wells near active gas-well areas and a mixed thermogenic-microbial source for those outside extraction areas. Molofsky and others $(2011,2013)$ report results of more than 1,700 pre-shale-gas-drilling analyses for methane in domestic well-water samples in Susquehanna County, northeastern Pennsylvania. They found (1) detectable methane (greater than $0.0001 \mathrm{mg} / \mathrm{L}$ ) in 78 percent of the wells, (2) significantly higher methane concentrations in lowland valley areas than in upland areas, and (3) no relation of methane concentrations to proximity of existing gas wells. Molofsky and others $(2011,2013)$ interpreted Susquehanna County, Pa., methane isotopic results from Osborn and others (2011) as consistent with a methane source of predominantly Upper Devonian strata (above the Marcellus Shale).

\section{Purpose and Scope}

This report documents the results of a survey of methane in groundwater from water wells of south-central New York conducted from late June through early August 2012 that utilized detailed well-construction data to assign a hydrogeologic 
setting classification for each well that was sampled. Sampling methods are described, and sample locations are mapped. Data on concentration and isotopic signatures of methane and other hydrocarbons are tabulated along with water-quality field characteristics, well-construction characteristics, elevation, and hydrogeologic setting. Graphs and plots show the range of methane concentration measured, statistical comparisons of methane concentration by hydrogeologic setting, comparisons of methane with water-quality field characteristics, and isotopic signatures of methane. A conceptual diagram of methane occurrence within the region with reference to hydrogeologic setting is presented and described.

\section{Methods}

Methods include hydrogeologic classification and selection of wells for the monitoring network, laboratory analysis, water sampling, quality control, and statistical analysis.

\section{Hydrogeologic Classification of Wells in the Study Area}

Evidence from previous work indicates that methane occurrence in groundwater is affected by the hydrogeologic setting - topographic position of the flow system and whether or not the groundwater is confined by glacial deposits (lacustrine deposits or till; Miller and Pittman, 2012; Heisig, 2012). Valleys are likely favorable for methane occurrence for multiple reasons. Valleys are areas of (1) maximum local incision (erosion) into bedrock strata, (2) closest proximity to underlying methane-bearing saline water or brine, and (3) locally weak (fractured and possibly faulted) bedrock with presumably more permeability than surrounding uplands, thus enhancing upward seepage of methane. Confinement by either unconsolidated deposits or bedrock of low permeability can trap the upward seepage of hydrocarbons. Thus, delineation of valleys and uplands and determination of confined or unconfined groundwater conditions are the basis of the classification used herein (table 1).

\section{Valleys and Uplands}

Valleys are conceptually the locus of groundwater discharge to surface water, mostly through shallow, permeable deposits under unconfined conditions. Beneath these deposits, confining units are commonplace with lacustrine fine sand, silt, and clay in large lowland valleys and till in narrow upland valleys. Groundwater circulation in sand and gravel and fractured bedrock beneath confining units is likely slower and more restricted than under shallow unconfined conditions. The depth of active circulation and the transition from fresh to saline water is shallowest beneath valleys (probably about or less than $300 \mathrm{ft}$ into bedrock).

Upland hillside and hilltop areas are primarily groundwater-recharge areas, and most groundwater flow is likely within the upper 100-300 ft of fractured bedrock (Heisig, 1999; Kipp and others, 1983). Groundwater flow is relatively rapid beneath high-gradient hillslopes with little till cover, which results in groundwaters with relatively low mineral content. Shallow fractures typically are unsaturated during dry periods and resaturate in response to recharge of rainfall or snowmelt. Where till cover is thick and confines bedrock, particularly on lower hillslopes or in till shadows (Coates, 1966), seasonal changes in saturation may be muted, and groundwater flow rates may be reduced. Groundwater flow in uplands converges downslope toward valley areas. Deep downward flow in uplands bedrock is also slow and restricted. The depth of active circulation and the transition from freshwater to brine is largely undocumented. Wells in the upland areas are almost exclusively completed in fractured bedrock, and reports of water with high salinity are rare. The deepest freshwater penetrated by gas wells in the uplands is reported to be about $800 \mathrm{ft}$ below land surface (Williams, 2010).

Table 1. Hydrogeologic setting classification in the study area, south-central New York.

\begin{tabular}{|c|c|c|c|c|c|c|c|c|c|c|c|}
\hline Tier & Characteristic & \multicolumn{10}{|c|}{ Setting } \\
\hline 1 & Topographic position & \multicolumn{6}{|c|}{ Valley } & \multicolumn{4}{|c|}{ Upland } \\
\hline 2 & Confinement & \multicolumn{3}{|c|}{ Confined } & \multicolumn{3}{|c|}{ Unconfined } & \multicolumn{2}{|c|}{ Confined } & \multicolumn{2}{|c|}{ Unconfined } \\
\hline 3 & Aquifer & & & $\begin{array}{l}\text { Sand and } \\
\text { gravel }\end{array}$ & Bedrock & Sand anc & d gravel & Bedrock & $\begin{array}{c}\text { Sand and } \\
\text { gravel } \\
\text { (none) }\end{array}$ & Bedrock & \begin{tabular}{|c|} 
Sand and \\
gravel \\
(none)
\end{tabular} \\
\hline 4 & $\begin{array}{l}\text { Hydrogeologic } \\
\text { subcategories }\end{array}$ & $\begin{array}{l}\text { Upland } \\
\text { valley }\end{array}$ & $\begin{array}{c}\text { Lowland } \\
\text { valley }\end{array}$ & & & $\begin{array}{c}\text { Sand and gravel } \\
\text { over bedrock }\end{array}$ & $\begin{array}{c}\text { Sand and } \\
\text { gravel over } \\
\text { confining unit }\end{array}$ & & & & \\
\hline
\end{tabular}


Valley and upland areas were delineated with the objective of differentiating wells by groundwater flow regime, as described above. Conceptually, a "valley" well is located on the valley floor or on immediately adjacent hillsides and completed below the elevation of the valley stream or river, either in sand and gravel or bedrock. An "upland" well is located on a hillside or hilltop and is completed almost exclusively in bedrock with the bottom of the well at an elevation typically higher than the adjacent valley stream or river.

The specifics of defining valleys, with the remaining land surface as uplands, follows and is illustrated in figure 3. First, a synthetic stream network was generated from a lidar (Light Detection and Ranging) digital elevation model (DEM). The longitudinal extent of streams that define valleys was defined by a drainage area of at least $0.58 \mathrm{mi}^{2}(1.5$ million square meters), stream-segment slopes of less than 2.75 percent, and local relief of greater than 150-200 ft. The width of valleys was defined as the land area vertically $75 \mathrm{ft}$ or less above the valley stream in small valleys with limited stratified glacial deposits. The same definition was used in large valleys with stratified glacial deposits, except where thick glacial deposits rise greater than $75 \mathrm{ft}$ above the valley stream; in those reaches, the valley extent was defined where regular valley hillside slopes begin (fig. 3 ).

\section{Confined Conditions}

Confinement by glacial-drift deposits of groundwater tapped by wells was addressed on a well-by-well or local basis, as comprehensive delineation across the study area was beyond the scope of this study and the availability of data. Although it is recognized that non-fractured bedrock with little primary permeability acts as a confining unit, classification of confined or unconfined conditions was based on the type of glacial-drift deposits overlying bedrock. The confinement condition of groundwater in upland and valley areas was determined by different criteria because of the differences in the types and distributions of glacial-drift deposits. Upland areas typically have a single type of glacial-drift deposit and confining unit (till) that partially overlies bedrock. Glacialdrift deposits in valley areas are more varied and consist of stratified materials that range from permeable ice-contact and outwash sand and gravel to relatively impermeable (confining) lacustrine fine sand, silt, and clay. Till is also a confining unit in some valley areas, typically just above bedrock, where present.

Confined and unconfined conditions in upland settings were defined through analysis of lidar imagery and well-log data. Comparison of these data indicate that till cover is thin or locally discontinuous where "stair-step" sedimentary bedrock structure is visible on lidar imagery and relatively thick where this pattern is obscured. The stair-step outcrop pattern in these gently dipping strata reflects the differences in bedrock resistance to erosion: sandstones are most resistant, and shales and siltstones are least resistant. In these areas till thickness can vary widely from absent (unconfined) on the outer edge of a "stair tread" to perhaps tens of feet (very locally confined) on inner parts of the tread - thus, unconfined on the whole. In light of these overall unconfined conditions, till thicknesses of $30 \mathrm{ft}$ or less (or less than or equal to $30 \mathrm{ft}$ of casing used) were considered unconfined settings, and till thicknesses of at least $45 \mathrm{ft}$ (greater than or equal to $60 \mathrm{ft}$ of casing) were considered confined. Wells that had greater than $30 \mathrm{ft}$ and less than $45 \mathrm{ft}$ of till thickness were of uncertain confinement and thus omitted from well selection.

Determination of confinement conditions in valley areas required well logs because of the stratified and unstratified nature of the glacial-drift deposits within a limited areal extent. Confined conditions were defined by a total of $15 \mathrm{ft}$ or more of fine-grained deposits (typically lacustrine deposits, less commonly till) above the top of screen, open end, or open bedrock wellbore. Unconfined conditions were defined as less than $15 \mathrm{ft}$ of fine-grained deposits.

\section{Additional Classification of Valley Settings}

Valley confined and unconfined settings were subdivided on the basis of (1) aquifer material — sand and gravel or bedrock, (2) sand and gravel wells over unconfined bedrock or sand and gravel wells over confined bedrock, and (3) confined bedrock wells in upland V-shaped valleys and lowland U-shaped valleys.

Valley confined and unconfined wells were subdivided by the aquifer in which a well was completed - sand and gravel or bedrock - because penetration of bedrock and greater depth within valley groundwater flow systems were considered potential factors in methane occurrence. Valley unconfined wells completed in sand and gravel were predominantly sand and gravel over bedrock (unconfined bedrock). A small subset of wells was completed in sand and gravel but locally isolated from bedrock by an underlying confining unit. The presence of an intervening confining unit could potentially prevent upward hydrocarbon seepage from reaching the unconfined sand and gravel.

Confined valley wells completed in bedrock were subdivided into lowland and upland categories. Lowland valleys are defined by streams or rivers below the 1,100 -ft elevation, and upland valleys are defined by streams at greater than or equal to the $1,100-\mathrm{ft}$ elevation. Lowland valleys contain stratified drift and have relatively flat valley bottoms (U-shaped valleys), whereas upland valleys are narrow, typically containing some alluvium that overlies till (V-shaped valleys).

\section{Monitoring-Well Network Criteria}

The well network was designed to evaluate methane concentrations in groundwater from the immediate groundwater environment of the sampling points. Wells within a 1-mile radius of any known current or former gas well in the study area or along the Pennsylvania border were excluded from consideration for sampling to avoid potential effects from 
$\boldsymbol{A}$

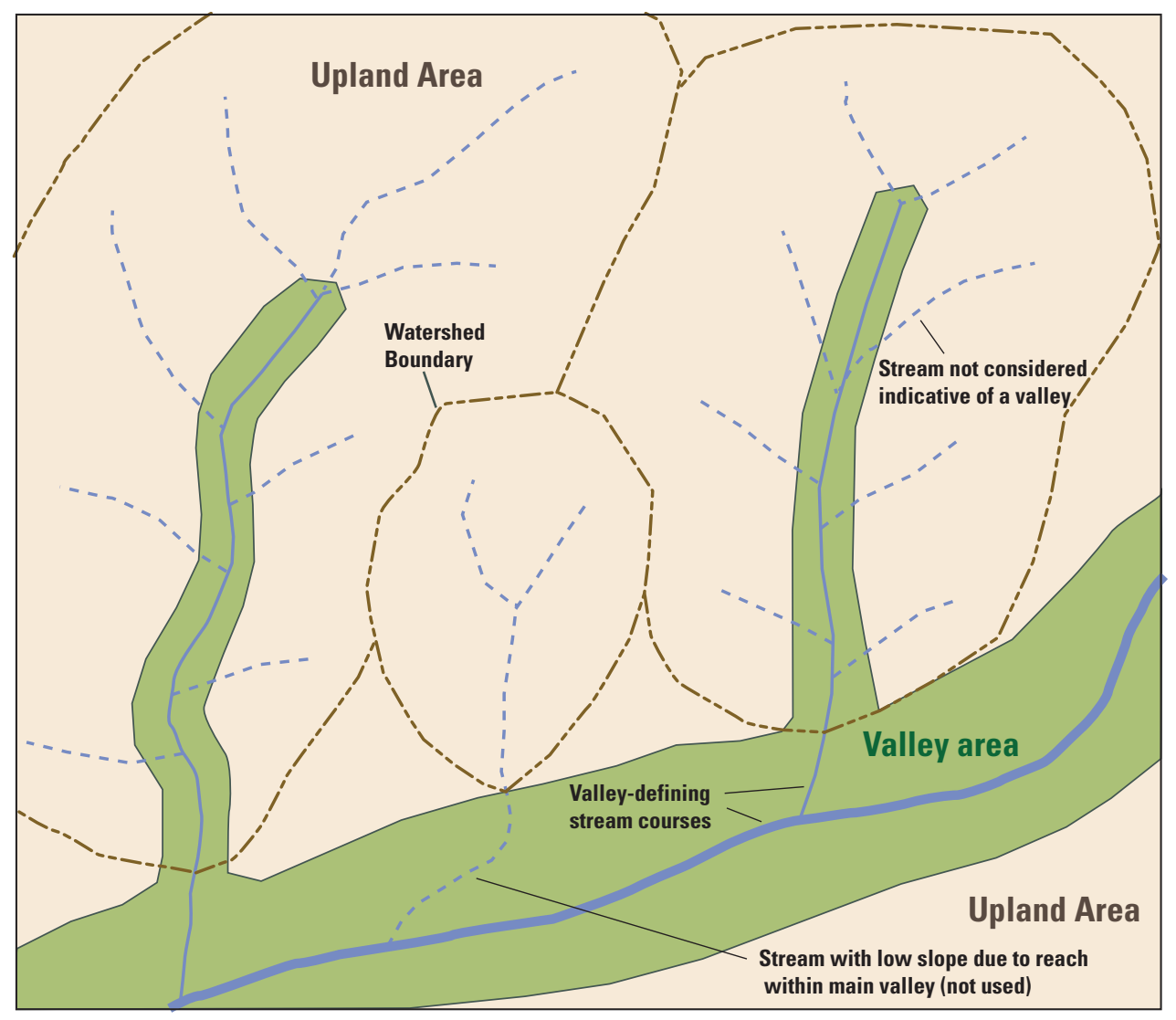

$\boldsymbol{B}$

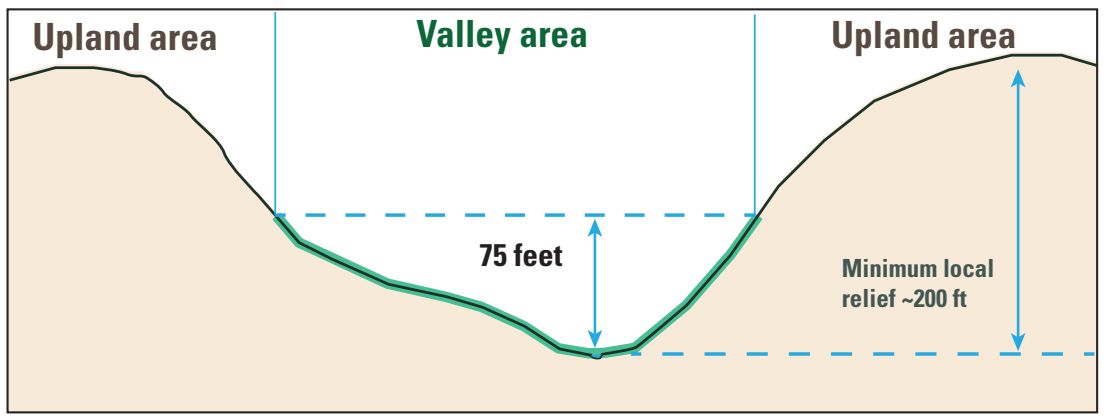

NOT TO SCALE

C

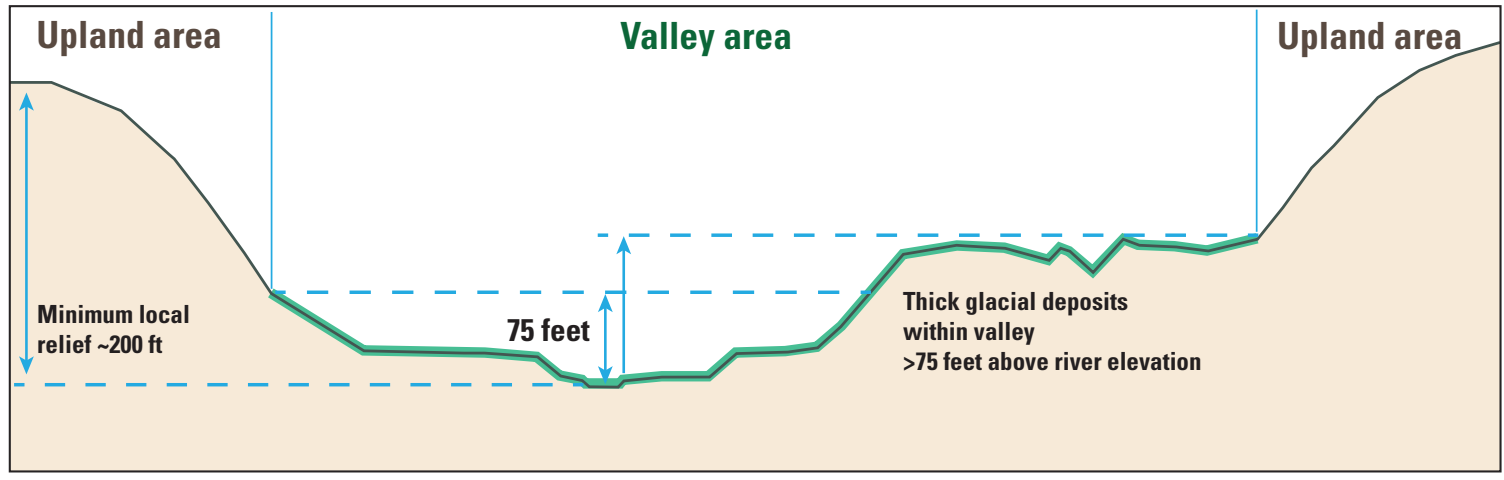

Figure 3. Schematic diagram defining $A$, valley areas and $B-C$, widths: $A$, Valley linear extent defined in map view. Digital elevation model generated stream courses (dashed and solid blue lines) with drainage areas greater than or equal to 0.58 square miles (1.5 million square meters). Solid blue lines indicate valley-defining stream courses (stream-segment slopes of less than 2.75 percent and local relief greater than approximately 200 feet). Dashed stream courses do not meet criteria and are not defined as valleys. $B$, Land area within 75 feet above the valley stream in small valleys with limited stratified glacial deposits. $C$, Large valleys with stratified glacial deposits are defined in a manner similar to that of small valleys, except where thick glacial deposits rise greater than 75 feet above the valley stream. Valley extent is defined where regular valley hillside slopes begin. (>, greater than; , approximately) 
current or historic gas wells (fig. 4). Most of the gas wells are in Chemung County (especially) and Tioga County, resulting in fewer candidate water wells in these areas. New York gas wells were identified by using the Empire State Oil and Gas Information System database (http://esogis.nysm.nysed. gov/) and the New York State Department of Environmental Conservation Oil and Gas database (http://www.dec.ny.gov/ cfmx/extapps/GasOil/), both of which include currently producing wells, plugged wells, destroyed wells, or other capped, non-producing test wells. Pennsylvania wells were identified by using the State's online gas-well database (http://www.portal.state.pa.us/portal/server.pt/community/ oil_and_gas_reports/20297). Low- to moderate-yielding water wells [reported yields of 2-80 gallons per minute ( $\mathrm{gal} / \mathrm{min})$ ], used mostly for household or livestock supply, were sampled, and high-yielding public supply or industrial-supply wells were avoided to ensure that groundwater from a relatively localized source was being sampled. Many high-yielding water wells derive a substantial part of their yield through induced infiltration from surface-water bodies and do not reflect local groundwater conditions. Wells of typical depth and well construction were sampled; depths of upland wells ranged from 100 to $350 \mathrm{ft}$, whereas depths of valley wells ranged from 28 to $225 \mathrm{ft}$. All wells completed in sand and gravel were finished with an open-ended casing; screens are rarely used for domestic wells. Bedrock wells are cased about $10 \mathrm{ft}$ into bedrock, and the remaining well is an open hole through the rock.

The initial target for the number of wells in the network was 60 with 15 wells in each of the four major hydrogeologic setting classes (valley confined, valley unconfined, upland confined, and upland unconfined). The primary source of information on wells with $\log$ and construction data was the New York State Department of Environmental Conservation Water Well Permit database (http://www.dec.ny.gov/ lands/33317.html). About 2,500 wells from this database are within the study area. Some wells about $0.25 \mathrm{mi}$ north (outside) of the Sonyea Group boundary in Chenango County were included in the pool of potential wells because of the coarse scale of the geology map (1:250,000 scale). This dataset was edited by removing (1) wells within 1 mile of a gas well, (2) upland wells within 1 mile of valley bottoms (in the original classification, these areas were considered transitional between uplands and valleys), and (3) wells with incomplete basic construction data or un-interpretable well logs. Upland wells cased between 30 and $60 \mathrm{ft}$ were omitted because of uncertain confinement conditions, as discussed under hydrogeologic settings. Valley wells that were shallow with no definition of underlying geology from driller's logs at nearby wells also were omitted. Upland wells were primarily categorized by casing length or, for some wells, by direct report of till thickness. Valley wells were categorized individually by well log or by existing surficial mapping. The resulting pool of potential wells consisted of 336 upland unconfined wells, 332 upland confined wells, 210 valley confined wells, and 135 valley unconfined wells. Letters explaining the study, along with well questionnaires, were sent to well owner addresses from the NYSDEC well permits. The network was developed from positive well-owner responses and questionnaire results, including accessibility and access to raw well water. The network consisted of 66 wells (with one upland well of uncertain confinement), 53 completed in bedrock and 13 completed in sand and gravel. There were 28 wells in Broome County, 19 wells in Tioga County, 11 wells in Chemung County, 7 wells in Chenango County, and 1 well in Delaware County (fig. 4). Descriptions of wells are presented in appendix 1, and selected well characteristics among major hydrogeologic settings are summarized in table 2 .

\section{Laboratory Analysis of Water Samples}

All samples were analyzed by Isotech Laboratories, Inc., (hereafter Isotech) in Champaign, Illinois. Isotech's NG-2 dissolved gas analytical schedule was used (appendix 2), which includes the molar percent of each dissolved gas [argon (Ar), oxygen $\left(\mathrm{O}_{2}\right)$, carbon dioxide $\left(\mathrm{CO}_{2}\right)$, nitrogen $\left(\mathrm{N}_{2}\right)$, carbon monoxide $(\mathrm{CO})$, methane $\left(\mathrm{CH}_{4}\right.$ or $\left.\mathrm{C}_{1}\right)$, ethane $\left(\mathrm{C}_{2} \mathrm{H}_{6}\right.$ or $\left.\mathrm{C}_{2}\right)$, and lower-chain hydrocarbons up to pentane $\left(\mathrm{C}_{5}\right)$ and the hexane $\left(\mathrm{C}_{6}\right)$ and longer chain fraction], the concentrations (milligrams per liter) of methane and ethane, and if sufficient sample, the carbon and hydrogen isotope ratios of methane and the carbon isotope ratio of ethane. Isotech uses a modified version of U.S Environmental Protection Agency's RSK175 method, a gas chromatography headspace equilibrium technique, for analysis of dissolved gases in water samples. Isotope ratio analyses are by either offline preparation with dual-inlet isotope ratio mass spectrometry (DI-IRMS) or online gas chromatography-combustion-isotope ratio mass spectrometry (GC-C-IRMS). Hydrogen stable isotope data are reported relative to Vienna Standard Mean Ocean Water (VSMOW), and carbon stable isotope data are reported relative to Vienna PeeDee Belemnite (VPDB).

Methane and other dissolved gases (carbon dioxide, nitrogen, oxygen, and argon) were analyzed in six samples by the USGS Reston Chlorofluorocarbon (CFC) Laboratory (appendixes 2-3) by gas chromatography. The argon, nitrogen, and oxygen are quantified by thermal conductivity detector. Methane and carbon dioxide are separated and passed through a nickel methanizer and measured with a Flame Ionization Detector (Busenberg and others, 1998; http://water.usgs.gov/ lab/dissolved-gas/lab/analytical_procedures/). These samples were analyzed by both laboratories so that a comparison could be made of the results from both methods. Until the present study, all dissolved methane groundwater data generated in New York State by the USGS had been analyzed using the CFC laboratory; in order to compare the results of the present study with results of previous studies of methane occurrence in groundwater (see Kappel and Nystrom, 2012), it was necessary to have methane data generated by both laboratories. 


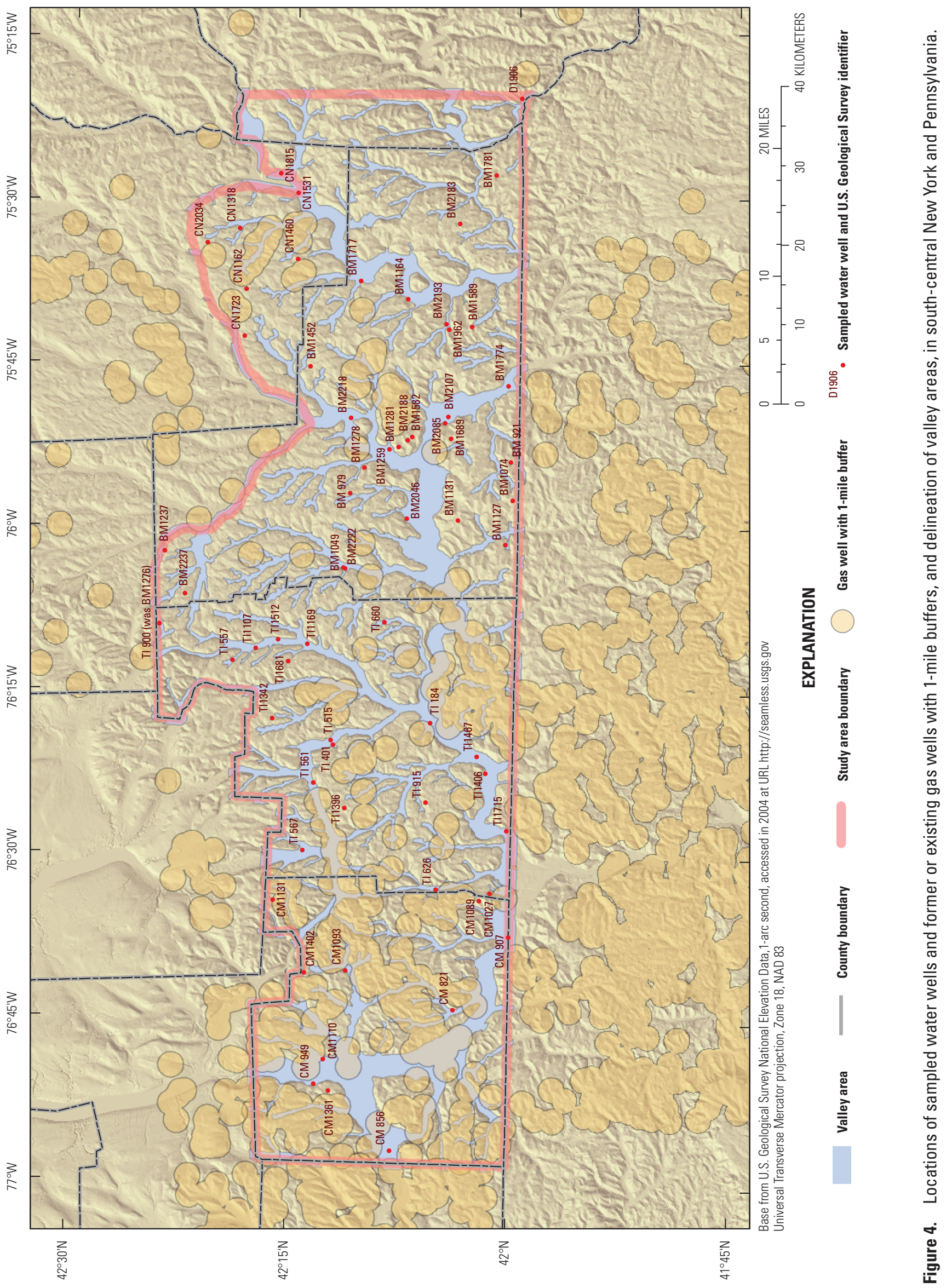




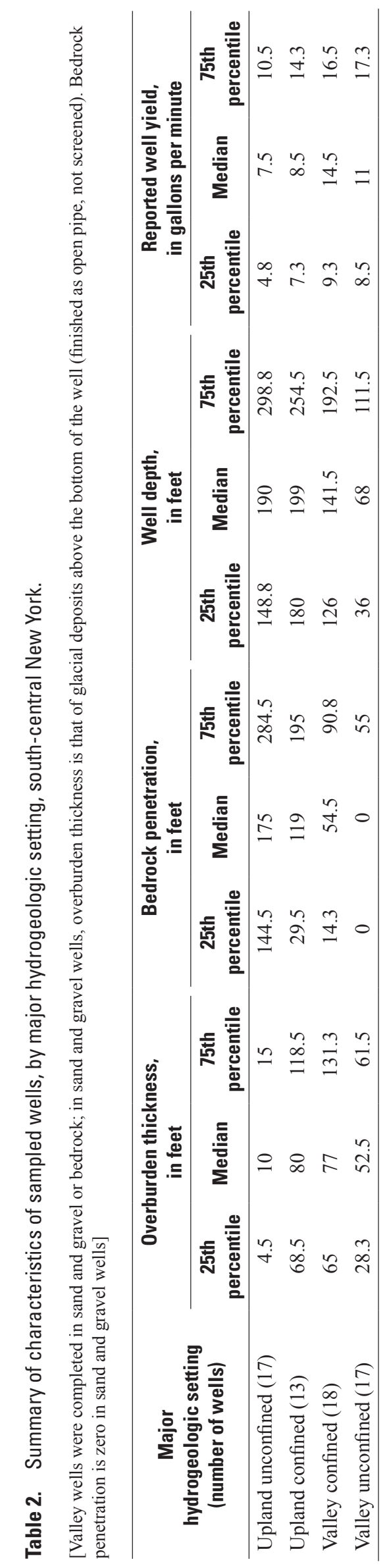




\section{Sampling Methods}

Samples were collected according to standard USGS sampling methods (U.S. Geological Survey, variously dated) with some modification as a result of well, plumbing, and accessibility conditions in the study area. Nearly all wells sampled were used regularly and thus regularly purged. Most wells were completed as open holes in fractured bedrock, and in the authors' experience with regional wellbores, active flow within such wellbores is commonplace. Therefore, stabilization of field water-quality characteristics was the criterion used to determine adequate well purging.

All water samples analyzed for dissolved gas were collected using the pump permanently installed in the well. Water was collected from a tap as close to the well as feasible, before the pressure tank where possible, and before any water-treatment system. Samples were collected using one or more 10-ft lengths of Teflon tubing attached to a spigot. Wells were purged at pumping rates on the order of 2-5 gallons per minute ( $\mathrm{gal} / \mathrm{min}$ ), and field characteristics (water temperature, $\mathrm{pH}$, specific conductance, and dissolved oxygen concentration) were recorded at regular intervals. Field water-quality characteristics were measured with a multi-parameter meter that received 1 to $2 \mathrm{gal} / \mathrm{min}$ of discharge water. Use of a flowthrough cell for field-characteristic measurement was modified when accumulation of gas bubbles was excessive and interfered with field-characteristic measurement. To minimize bubble accumulation, the discharge line was strapped to the field-characteristic probe and placed in a beaker (to restrict fresh discharge near the probe) that was then placed in the bottom of a 5-gallon bucket that received the discharge water. This procedure also served to keep the discharge water and field probes close to ambient groundwater temperatures during summer field work. Temperature of the discharge water and pressure at the well-system pressure gage were monitored to verify that the well was cycling on and off at regular intervals such that the sample was as representative of well water as possible.

Sampling began after at least two, but typically all four, of the field characteristics had met stabilization criteria (U.S. Geological Survey, variously dated). All samples were collected after at least 20 minutes of purging. During well purging, recent water use by the well owner was noted, and the well location was sketched on a map and verified with a global positioning system (GPS) measurement of latitude and longitude.

Dissolved-gas samples were collected through a manifold system attached to the end of the Teflon tubing (http://www.isotechlabs.com/customersupport/samplingprocedures/IsoBagSM.pdf) that consisted of a pressure gage, a purge valve that allowed discharge to continue to waste, and a sampling valve that allowed reduced flow for sampling purposes. During sample collection, back pressure was put on the well-water discharge by partially closing both valves to minimize degassing in the Teflon tubing up to the sample-line valve. Back pressures ranged from about 5 to 25 pounds per square inch, depending on the sample. During sample collection, the flow rate in the sample line was adjusted to about $0.5 \mathrm{gal} / \mathrm{min}$. Effervescent samples were collected in IsoBags ${ }^{\circledR}$ (Isotech Laboratories, Inc.), which are evacuated flexible plastic bags (with biocide capsule) with a valve that connects to the sample line to prevent loss of gas during sample collection (http://www.isotechlabs.com/customersupport/samplingprocedures/IsoBagSM.pdf). Samples with little or no effervescence were collected through the same manifold, completely filling, from the bottom, the 1-liter polyethylene terephthalate bottle septum cap with biocide capsule and then filling the equivalent of two more bottle volumes while the bottle was submerged in the bottom of a full 5-gallon bucket (Isotech Laboratories, Inc., http://www.isotechlabs.com/customersupport/samplingprocedures/DGbottle.pdf; CFC laboratory http://water.usgs. gov/lab/dissolved-gas/sampling/). All samples analyzed by the CFC laboratory were collected in 125 -milliliter $(\mathrm{mL})$ glass serum bottles using the same filling method regardless of the presence or absence of effervescence. The Teflon tubing, spigot-attachment equipment, and manifolds were initially cleaned in the laboratory prior to field work with a dilute Liquinox solution, followed by tap water and deionized water. In the field, the sample tubing and manifold were flushed with 1 liter of deionized water after each sample was collected. Water samples were collected in bottles provided by each analyzing laboratory.

Following sample collection, all samples were chilled to 4 degrees Celsius $\left({ }^{\circ} \mathrm{C}\right)$ or less. Isotech samples were shipped overnight at the end of each sampling day, and CFC laboratory samples were shipped overnight at the end of each sampling week.

\section{Quality-Control Samples}

In addition to the 66 groundwater samples, replicate samples and field blank samples were collected. Replicate differences were computed for three different types of comparisons: (1) replicate results with sample results from Isotech, (2) replicate results with sample results from the CFC laboratory, and (3) Isotech results with CFC laboratory results.

\section{Isotech Analyses}

Discussions below generally focus on the most important compounds or measurements; these include concentrations in milligrams per liter $(\mathrm{mg} / \mathrm{L})$ of methane, hydrogen $(\delta \mathrm{D})$ and carbon $\left(\delta^{13} \mathrm{C}\right)$ isotope ratios of methane, and carbon $\left(\delta^{13} \mathrm{C}\right)$ isotope ratios of ethane (appendix 4). In general, results of comparisons of other constituents (such as $\mathrm{Ar}, \mathrm{O}_{2}, \mathrm{CO}_{2}, \mathrm{~N}_{2}, \mathrm{C}_{1}$, and $\mathrm{C}_{2}$, through $\mathrm{C}_{6}+$ ) are limited to those constituents with five or more comparisons $\left(\mathrm{Ar}, \mathrm{O}_{2}, \mathrm{CO}_{2}, \mathrm{~N}_{2}\right)$. Percent difference for 
Isotech results is defined as the difference between concentrations for two samples divided by the mean concentration.

Nine replicate samples were analyzed by the Isotech laboratory; concentrations were greater than the detection limit for eight of these samples. Percent differences in methane concentrations were generally low (median 7.85 percent) for the eight pairs of Isotech laboratory replicate samples; percent differences ranged from 0 to 19 percent, indicating good reproducibility. Methane concentrations for these samples were generally high with all concentrations greater than $1 \mathrm{mg} / \mathrm{L}$. The eight replicates with methane detections included two replicates in bottles (percent differences ranging from 0 to 8.7 percent); three replicates in bags (percent differences ranging from 0 to 7.3 percent); and three container replicates, one in a bottle and one in a bag (percent differences ranging from 15 to 19 percent). Bottle concentrations were higher than corresponding bag concentrations in all three samples.

Replicate differences for concentrations in the headspace of samples for other constituents were low, generally less than 10 percent. The median percent difference for ethane, detected in more than five samples, was 2.44 percent, and median differences in hydrogen $(\delta \mathrm{D})$ and carbon $\left(\delta^{13} \mathrm{C}\right)$ isotope ratios of methane were less than 1 percent. A large difference was found for the sample from well CM856 between hydrogen isotope ratios $(\delta \mathrm{D})$ in replicates $(-6$ and -17.4 , ratio differences, respectively).

Replicate differences for four other gases $\left(\mathrm{Ar}, \mathrm{O}_{2}, \mathrm{CO}_{2}\right.$, and $\mathrm{N}_{2}$ ) were all generally low, with median differences ranging from less than 1 to 11 percent. Ethane also had low replicate differences with medians ranging from 0 to 8 percent.

\section{Reston Chlorofluorocarbon Laboratory Analyses}

Six samples and their replicates were analyzed by the CFC laboratory (appendix 3); of these, methane was detected in four samples and their replicates. All six samples contained concentrations of the remaining four dissolved gases analyzed (Ar, $\mathrm{O}_{2}, \mathrm{CO}_{2}$, and $\mathrm{N}_{2}$ ). Percent difference for CFC laboratory results was defined as the difference between concentrations in two samples divided by the mean concentration. Percent differences for the methane replicates were all less than 7 percent, with a median of 4.5 percent. Median percent differences for the other dissolved gases were less than 9 percent.

\section{Comparison of Isotech and Reston Chlorofluorocarbon Laboratory Analyses}

All but one of the five Isotech samples with a corresponding CFC laboratory sample were replicate samples, resulting in four samples with four concentration comparisons between the two laboratory results and one sample with two concentration comparisons. The Isotech laboratory sample with only one result had a very low methane concentration
$(<0.001 \mathrm{mg} / \mathrm{L})$; the corresponding CFC laboratory samples had non-detections. This comparison is not included in the analysis. All the comparisons of the CFC laboratory methane data with the Isotech laboratory data for concentrations greater than $0.01 \mathrm{mg} / \mathrm{L}$ showed that the CFC laboratory had consistently higher concentrations than the Isotech laboratory. For these comparisons, percent difference was calculated as the concentration of the Isotech laboratory result minus that of the CFC laboratory result divided by the average concentration of both results. Differences in concentrations ranged from a minimum of 9 percent higher to 41 percent higher for the CFC laboratory concentrations compared to those from the Isotech laboratory with a median of 19 percent higher concentrations for CFC laboratory results. Because concentrations for the Isotech laboratory samples in this comparison range from 1.9 to $12 \mathrm{mg} / \mathrm{L}$, these results may not apply to lower concentrations.

\section{Blank Analyses}

Two field blanks were included in the analyses to assess potential methane contamination in the field. The two blank samples were collected using volatile organic carbon (VOC) grade, nitrogen purged organic free water obtained from the USGS National Water Quality Laboratory (NWQL) and were processed similar to field samples. One of the field blank samples had a non-detection for methane, whereas the other sample had a detection at $0.00019 \mathrm{mg} / \mathrm{L}$. Although this reported concentration of methane is very low, in order to prevent any false positive reporting for methane concentrations in field samples, all methane concentrations at or less than $0.001 \mathrm{mg} / \mathrm{L}$ (5 times the blank concentration) were treated as non-detects. This resulted in the censoring of 14 concentrations but had no major effect on the interpretation of methane data given the very low concentrations in these samples (see fig. 5 for distribution among settings).

\section{Statistical Methods}

Non-parametric statistics were used in this study to compare methane concentrations between different well types. Non-parametric statistics are appropriate for use with data (such as those in this study) that are not normally distributed (Helsel and Hirsch, 2002), and ranked data were used in this study to assess statistical differences between different groups. In general, comparisons of methane data between different groups of wells were first tested using the Tukey test to assess whether there were any significant differences between median concentrations for any of the well groups. If this analysis indicated any significant differences in median concentrations, a Kruskal-Wallace test ( $p$-value less than 0.05) was used to assess which median concentrations differed among the groups. 

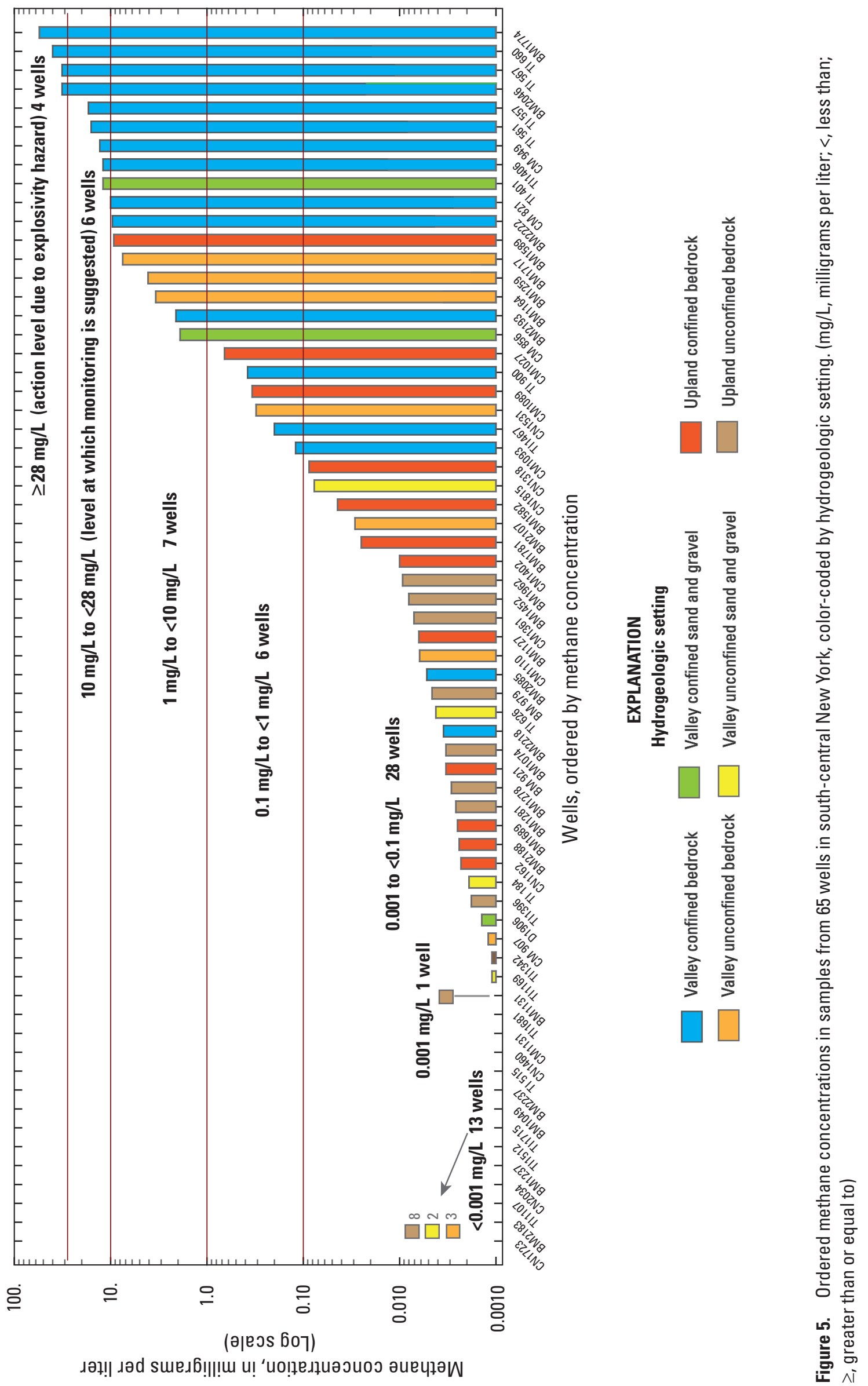


\section{Methane Occurrence in Groundwater}

Data on field characteristics and gases from Isotech laboratory analyses of samples collected from 66 wells are listed in appendix 4. Measurable methane in the sampled groundwater was commonplace; concentrations greater than or equal to $0.001 \mathrm{mg} / \mathrm{L}$ were present in 78 percent of samples (fig. 5). The concentration range extended over 5 orders of magnitude. Nine percent of methane concentrations ranged from 10 to less than $28 \mathrm{mg} / \mathrm{L}$, the range in which periodic monitoring is indicated (Eltschlager and others, 2001). Six percent equaled or exceeded $28 \mathrm{mg} / \mathrm{L}$, which is the solubility of methane at atmospheric pressure and considered an explosivity hazard; mitigation is indicated at this concentration (Eltschlager and others, 2001). The maximum concentration was $55 \mathrm{mg} / \mathrm{L}$.

Ethane was present in 14 samples at concentrations of 0.0001 to $0.047 \mathrm{mg} / \mathrm{L}$, and those same samples had methane concentrations from 0.2 to $55 \mathrm{mg} / \mathrm{L}$. Ethene was detected in one sample. No other hydrocarbons exceeded headspace volume percentages of 0.001 . The methane to ethane mass ratio in the sample with the highest methane and ethane concentrations was 1,170 , which is indicative of a "dry gas" (Schoell, 1980).

\section{Methane Concentrations and Hydrogeologic Setting}

The overall distribution of methane concentration is associated with hydrogeologic setting (fig. 5). Methane concentrations greater than or equal to $0.1,5$, and $10 \mathrm{mg} / \mathrm{L}$ were generally associated with wells completed in the confined valley setting or unconfined valley setting, if completed in bedrock. The lowest methane concentrations, less than $0.1 \mathrm{mg} / \mathrm{L}$, were generally associated with unconfined upland bedrock and unconfined valley sand and gravel settings.

Statistical comparisons (Kruskal-Wallis test) of methane concentrations among water samples from the first two tiers of hydrogeologic setting from table 1 (topographic position and confinement) indicate that the highest concentrations of methane generally occur in valley and confined settings. Results of the tests for statistical differences among settings are depicted with boxplots in figures 6A-B. These data indicate that both valley setting and confinement were important factors in groundwater methane occurrence. The valley confined setting samples exhibited the highest methane concentrations and were statistically different ( $p$-value less than 0.05 ) from the other three settings. Valley unconfined and upland confined settings had the next highest methane concentrations and were not statistically different from one another. The upland unconfined setting had the lowest methane concentrations and was statistically different from the upland confined settings but not statistically different from valley unconfined settings.

Methane concentrations from the third tier of hydrogeologic setting in table 1 (aquifer) are shown in (fig. 6B). The hydrogeologic subcategories were limited to the valley setting; the subcategories were also tested for statistical differences. Bedrock and sand and gravel aquifer settings confined by glacial deposits exhibited high methane concentrations, which are consistent with the accumulation of upward seepage below confining units and relatively slow groundwater flow. Bedrock unconfined by glacial deposits also exhibited high methane concentrations that were not statistically different from those for confined bedrock. Groundwater flow within bedrock in valleys is likely relatively slow, and bedrock itself provides variable degrees of confinement. These results imply that the valley bedrock setting is strongly associated with methane occurrence.

Methane concentrations in unconfined sand and gravel were statistically lower than concentrations for the other valley groups (fig. 6B). This category includes wells completed in sand and gravel above bedrock and some wells completed in sand and gravel above a confining layer over bedrock. The low concentrations are consistent with the conceptualization that shallow, relatively fast unconfined groundwater flow regimes have short residence times prior to discharge that limit exposure time for methane accumulation and allow dissipation of upward methane seepage to the atmosphere or microbial oxidation of methane. Confining units beneath wells completed in sand and gravel limit the upward seepage of methane from bedrock.

The patterns of methane occurrence by hydrogeologic setting across a range of minimum concentrations $(0.1,5$, and $10 \mathrm{mg} / \mathrm{L}$ ) are consistent at the greater than 0.1 and $5 \mathrm{mg} / \mathrm{L} \mathrm{lev-}$ els (tables $3 \mathrm{~A}-\mathrm{B}$ ) and encompass thermogenic and microbial origins in both valley and confined bedrock upland settings. Methane concentrations of $10 \mathrm{mg} / \mathrm{L}$ or greater, however, were limited to valley settings (excluding the valley unconfined sand and gravel setting). The highest concentrations (greater than or equal to $28 \mathrm{mg} / \mathrm{L}$ ) are found only in confined bedrock aquifers in valleys (noted in table $3 \mathrm{C}$ ).

\section{Methane Concentrations and Field- Characteristic Measurements}

Field measurements made during sampling provide a general water-chemistry context for methane concentrations. Groundwater samples from wells completed in bedrock are a composite of water from one or more producing fracture(s) with potentially different water chemistry. Bedrock wells that penetrate considerable bedrock thicknesses (typically less in valleys than in uplands) likely derive most of their yield from shallower fractures, but it is possible that some wells derive most of their yield from deeper fractures. Thus, field characteristics and methane concentrations likely do not represent a single groundwater chemistry, unless the well derives its yield from a single fracture. Nevertheless, general trends are evident. Methane occurrence in groundwater flow systems represents highly reducing redox conditions under which the absence of dissolved oxygen and the presence of hydrogen sulfide would be expected. However, if methane has migrated upward from beneath the active groundwater flow system, 


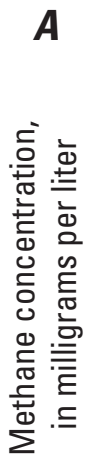

A

UPLAND

VALLEY

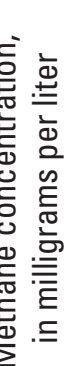

0.100
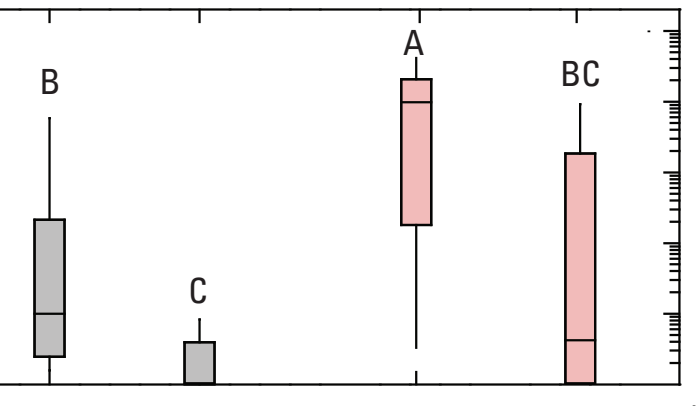$$
0.0
$$$$
\text { , }
$$

लㄹ

B

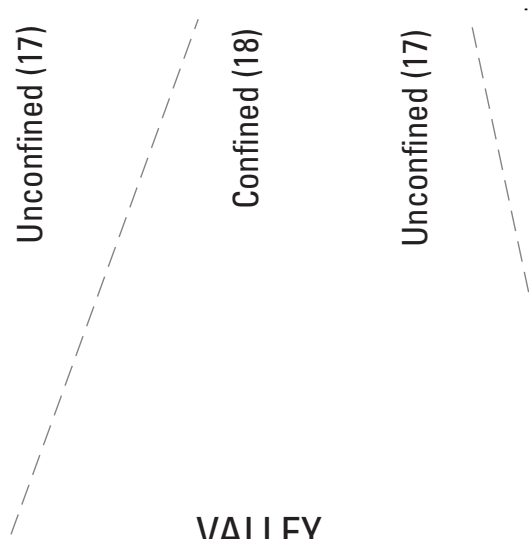

\begin{tabular}{|l}
90 \\
75 \\
50 \\
25 \\
25 \\
10
\end{tabular}

A Different letters indicate significant differences by Kruskal-Wallis test

Individual point plotted for sample types with less than 12 observations

(3) Number of samples

Rose colored symbols indicate valley settings

Figure 6. Distribution of methane concentrations in samples from south-central New York water wells, 2012, by hydrogeologic setting, for $A$, wells classified by topographic position and whether or not confined by glacial drift deposits and $B$, valley setting wells by well-completion in sand and gravel or bedrock. Statistical comparison does not include confined sand and gravel due to small number of samples $(n=3)$ in this category. 
Table 3. Hydrogeologic classification of wells sampled, with each class color coded by percentage of samples with methane concentrations greater than or equal to: $A, 0.1$ milligram per liter, $B, 5$ milligrams per liter, and $C, 10$ milligrams per liter in south-central New York, 2012.

$[\geq$, greater than or equal to; $<$, less than; mg/L, milligrams per liter; $\%$, percent; $(\mathrm{X})$, number of samples $]$

Percentage of samples greater than or equal to listed methane concentration

\begin{tabular}{|c|c|c|c|c|c|c|c|c|c|c|c|}
\hline 0 & \multicolumn{2}{|c|}{$>0$ to $<20$} & 20 to $<40$ & \multicolumn{3}{|c|}{60 to $<80$} & 80 to 100 & & & & \\
\hline \multicolumn{12}{|c|}{ A. Methane concentration $\geq 0.1 \mathrm{mg} / \mathrm{L}$} \\
\hline Tier & Characteristic & \multicolumn{10}{|c|}{ Setting } \\
\hline 1 & $\begin{array}{l}\text { Topographic } \\
\text { position }\end{array}$ & \multicolumn{6}{|c|}{$\begin{array}{l}\qquad \text { Valley (35) } 57 \% \\
\text { Primarily thermogenic methane source, with some indication of mixing with } \\
\text { microbially derived (carbon-dioxide reduction) methane from subregional } \\
\text { groundwater flow system }\end{array}$} & \multicolumn{4}{|c|}{$\begin{array}{l}\text { Upland ( } 30) 10 \% \\
\text { Primarily microbial (carbon-dioxide reduction) source of } \\
\text { methane, with indication of mixing with thermogenic } \\
\text { methane or oxidation of microbial methane in some samples }\end{array}$} \\
\hline 2 & $\begin{array}{l}\text { Confinement } \\
\text { by glacial } \\
\text { deposits }\end{array}$ & \multicolumn{3}{|c|}{ Confined (18) $83 \%$} & \multicolumn{3}{|c|}{ Unconfined (17) $29 \%$} & \multicolumn{2}{|c|}{ Confined (13) $23 \%$} & \multicolumn{2}{|c|}{ Unconfined (17) $0 \%$} \\
\hline 3 & Aquifer & \multicolumn{2}{|c|}{ Bedrock (15) $87 \%$} & $\begin{array}{l}\text { Sand and gravel } \\
\text { (3) } 67 \%\end{array}$ & $\begin{array}{l}\text { Bedrock } \\
\text { (8) } 63 \%\end{array}$ & \multicolumn{2}{|c|}{ Sand and gravel (9) $0 \%$} & $\begin{array}{l}\text { Bedrock } \\
\text { (13) } 23 \%\end{array}$ & $\begin{array}{c}\text { Sand and gravel } \\
(0)\end{array}$ & $\begin{array}{l}\text { Bedrock } \\
\text { (17) } 0 \%\end{array}$ & $\begin{array}{c}\text { Sand and gravel } \\
\text { (0) }\end{array}$ \\
\hline 4 & $\begin{array}{l}\text { Hydrogeologic } \\
\text { subcategories }\end{array}$ & $\begin{array}{l}\text { Upland } \\
\text { valley (5) } \\
100 \%\end{array}$ & $\begin{array}{l}\text { Lowland } \\
\text { valley (10) } \\
\quad 80 \%\end{array}$ & & & $\begin{array}{l}\text { Sand and } \\
\text { gravel } \\
\text { over } \\
\text { bedrock } \\
\text { (6) } 0 \%\end{array}$ & $\begin{array}{l}\text { Sand and gravel } \\
\text { over confining } \\
\text { unit (3) } 0 \%\end{array}$ & & & & \\
\hline
\end{tabular}

B. Methane concentration $\geq 5 \mathrm{mg} / \mathrm{L}$

\begin{tabular}{|c|c|c|c|c|c|c|c|c|c|c|c|}
\hline Tier & Characteristic & \multicolumn{10}{|c|}{ Setting } \\
\hline 1 & $\begin{array}{l}\text { Topographic } \\
\text { position }\end{array}$ & \multicolumn{6}{|c|}{ Valley (35) 34\% } & \multicolumn{4}{|c|}{ Upland (30) 3\% } \\
\hline 2 & $\begin{array}{l}\text { Confinement } \\
\text { by glacial } \\
\text { deposits }\end{array}$ & \multicolumn{3}{|c|}{ Confined (18) $56 \%$} & \multicolumn{3}{|c|}{ Unconfined (17) 12\% } & \multicolumn{2}{|c|}{ Confined (13) $8 \%$} & \multicolumn{2}{|c|}{ Unconfined (17) $0 \%$} \\
\hline 3 & Aquifer & Bedrocl & (15) $60 \%$ & $\begin{array}{l}\text { Sand and gravel } \\
\text { (3) } 33 \%\end{array}$ & $\begin{array}{l}\text { Bedrock } \\
\text { (8) } 25 \%\end{array}$ & Sand an & d gravel (9) $0 \%$ & $\begin{array}{l}\text { Bedrock } \\
\text { (13) } 8 \%\end{array}$ & $\begin{array}{l}\text { Sand and gravel } \\
\text { (no wells) }\end{array}$ & $\begin{array}{l}\text { Bedrock } \\
\text { (17) } 0 \%\end{array}$ & $\begin{array}{l}\text { Sand and gravel } \\
\text { (no wells) }\end{array}$ \\
\hline 4 & $\begin{array}{l}\text { Hydrogeologic } \\
\text { subcategories }\end{array}$ & $\begin{array}{c}\text { Upland } \\
\text { valley (5) } \\
40 \%\end{array}$ & $\begin{array}{c}\text { Lowland } \\
\text { valley (10) } \\
70 \%\end{array}$ & & & $\begin{array}{c}\text { Sand and } \\
\text { gravel } \\
\text { over } \\
\text { bedrock } \\
\text { (6) } 0 \% \\
\end{array}$ & $\begin{array}{l}\text { Sand and gravel } \\
\text { over confining } \\
\text { unit (3) } 0 \%\end{array}$ & & & & \\
\hline
\end{tabular}

\begin{tabular}{|c|c|c|c|c|c|c|c|c|c|c|c|}
\hline \multicolumn{12}{|c|}{ C. Methane concentration $\geq 10 \mathrm{mg} / \mathrm{L}$} \\
\hline Tier & Characteristic & \multicolumn{10}{|c|}{ Setting } \\
\hline 1 & $\begin{array}{l}\text { Topographic } \\
\text { position }\end{array}$ & \multicolumn{6}{|c|}{ Valley (35) $29 \%$} & \multicolumn{4}{|c|}{ Upland (30) $0 \%$} \\
\hline 2 & $\begin{array}{l}\text { Confinement } \\
\text { by glacial } \\
\text { deposits }\end{array}$ & \multicolumn{3}{|c|}{ Confined (18) $50 \%$} & \multicolumn{3}{|c|}{ Unconfined (17) $6 \%$} & \multicolumn{2}{|c|}{ Confined (13) $0 \%$} & \multicolumn{2}{|c|}{ Unconfined (17) $0 \%$} \\
\hline 3 & Aquifer & \multicolumn{2}{|c|}{ Bedrock (15) $53 \%$} & $\begin{array}{l}\text { Sand and gravel } \\
\text { (3) } 33 \%\end{array}$ & $\begin{array}{l}\text { Bedrock } \\
\text { (8) } 13 \% \\
\end{array}$ & \multicolumn{2}{|c|}{ Sand and gravel (9) $0 \%$} & $\begin{array}{l}\text { Bedrock } \\
\text { (13) } 0 \% \\
\end{array}$ & $\begin{array}{l}\text { Sand and gravel } \\
\text { (0) }\end{array}$ & $\begin{array}{l}\text { Bedrock } \\
\text { (17) } 0 \% \\
\end{array}$ & $\begin{array}{c}\text { Sand and gravel } \\
\text { (0) }\end{array}$ \\
\hline 4 & $\begin{array}{l}\text { Hydrogeologic } \\
\text { subcategories }\end{array}$ & $\begin{array}{c}\text { Upland } \\
\text { valley (5) } \\
40 \% \\
(1 \geq 28 \mathrm{mg} / \mathrm{L})\end{array}$ & $\begin{array}{c}\text { Lowland } \\
\text { valley (10) } \\
60 \% \\
(3 \geq 28 \mathrm{mg} / \mathrm{L})\end{array}$ & & & $\begin{array}{c}\text { Sand and } \\
\text { gravel } \\
\text { over } \\
\text { bedrock } \\
\text { (6) } 0 \% \\
\end{array}$ & $\begin{array}{l}\text { Sand and gravel } \\
\text { over confining } \\
\text { unit (3) } 0 \%\end{array}$ & & & & \\
\hline
\end{tabular}


methane occurrence and redox conditions may not be consistent. In samples with methane concentration of $0.5 \mathrm{mg} / \mathrm{L}$ or greater, the concentration of dissolved oxygen was $0.2 \mathrm{mg} / \mathrm{L}$ or less in all but one sample, and hydrogen sulfide was detected in all but one sample.

$\mathrm{pH}$ and specific conductance typically increase with time in non-carbonate groundwater flow systems but reach their highest values in wells that tap transitional water of increasing salinity with depth between the freshwater flow system and underlying brine (Heisig, 1999; fig. 34). This transition zone likely represents incomplete flushing of pre-existing brine by the freshwater flow system (Poth, 1963). Thus, comparison of methane concentration to $\mathrm{pH}$ and specific conductance by valley and upland settings (fig. 7) can be useful in understanding methane occurrence.

Methane concentration generally correlated with $\mathrm{pH}$ in upland and valley settings at $\mathrm{pHs}$ of 7.7 and above; in valley areas, all methane concentrations exceeded $1 \mathrm{mg} / \mathrm{L}$ at $\mathrm{pH} 8.0$ and greater (fig. 7). This implies that methane occurrence at concentrations greater than $1 \mathrm{mg} / \mathrm{L}$ is associated with older, mostly anoxic groundwater, rather than recent groundwater. One exception to this association was a sample from a valley confined setting with a methane concentration of $9.6 \mathrm{mg} / \mathrm{L}$ and a $\mathrm{pH}$ of 7.4 (the water was anoxic - dissolved oxygen was $0.1 \mathrm{mg} / \mathrm{L}$ ). This could be the result of high upward seepage rates of methane into younger confined groundwater at this locale.

Specific conductance generally correlated with methane concentration but only at the highest end of the specificconductance range. In valley areas, however, high methane concentrations can also occur at relatively low specific conductances [340-570 microsiemens per centimeter $(\mu \mathrm{S} /$ $\mathrm{cm})$ at 25 degrees Celsius $\left({ }^{\circ} \mathrm{C}\right)$; fig. 7]. Three of four methane concentrations greater than $0.1 \mathrm{mg} / \mathrm{L}$ in upland areas correspond to specific conductances of greater than $750 \mu \mathrm{S} / \mathrm{cm}$ at $25^{\circ} \mathrm{C}$. The one upland unconfined sample with high specific

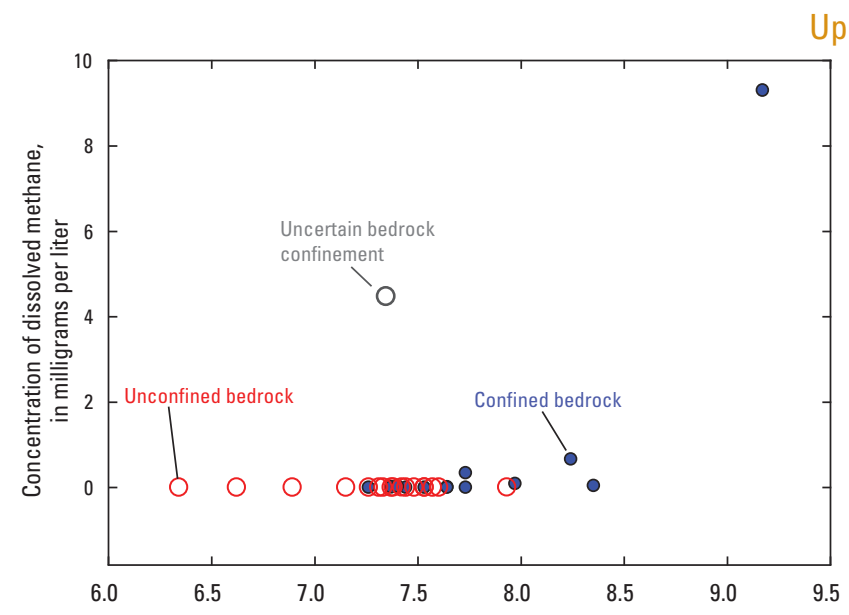

Jpland Areas
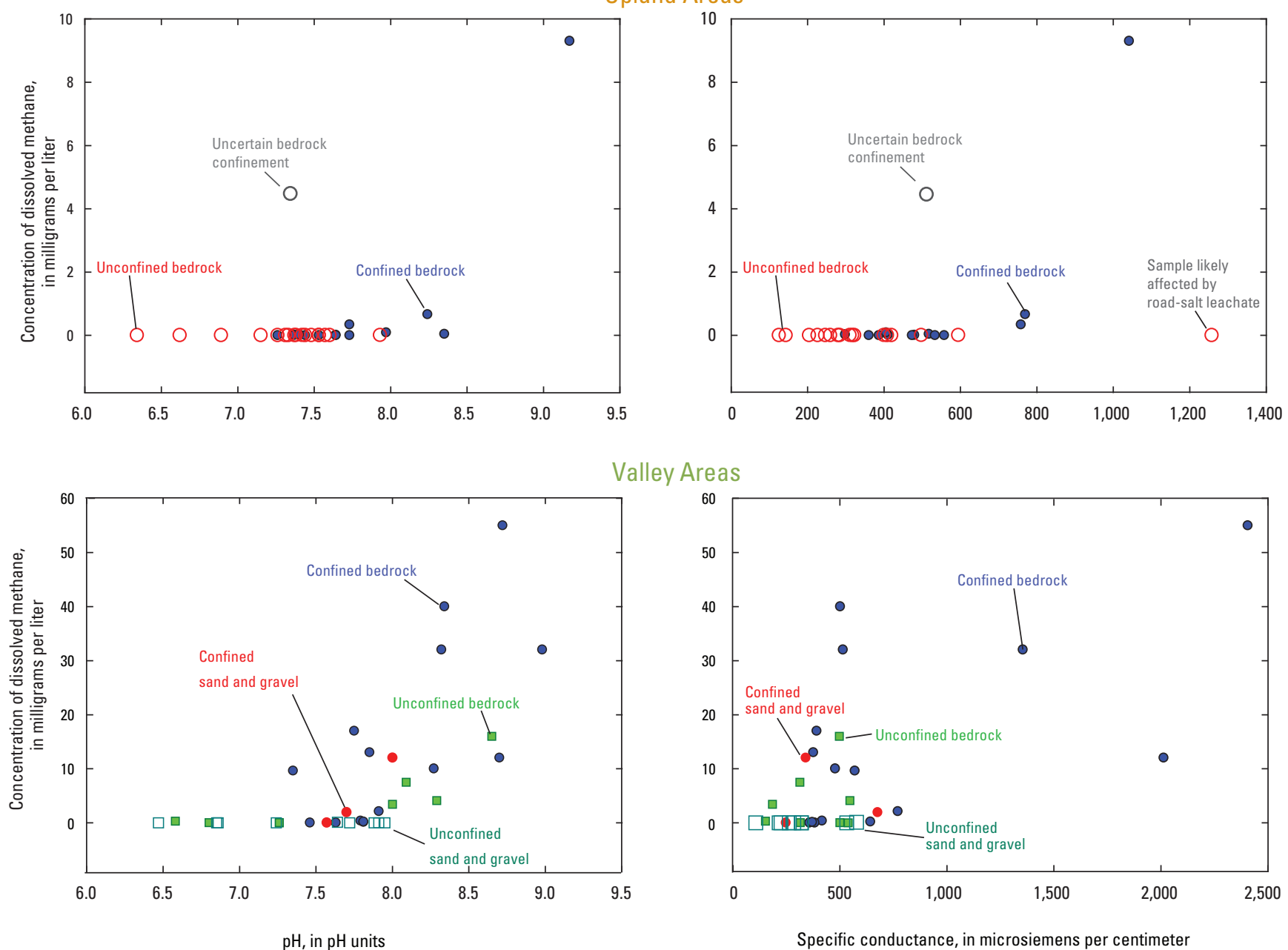

Valley Areas

Figure 7. Methane concentrations in relation to $\mathrm{pH}$ and specific conductance in valley and upland areas. Note difference in methane and specific conductance scales between upland and valley areas. 
conductance and no methane possibly indicates a non-natural source of the dissolved solids, which are elevated above background levels [such as road salt or septic (water softener) leachate]. In valley areas, all samples with specific conductance greater than $675 \mu \mathrm{S} / \mathrm{cm}$ at $25^{\circ} \mathrm{C}$ had methane concentrations greater than $1 \mathrm{mg} / \mathrm{L}$. Below $675 \mu \mathrm{S} / \mathrm{cm}$ at $25^{\circ} \mathrm{C}$, specific conductance was not a useful indicator of methane occurrence because methane concentrations ranged widely across the range of specific-conductance values.

\section{Methane Concentrations and Well Completion}

Well completion details (bedrock penetration, elevation of well bottom, and confining-unit thickness) were compiled to illustrate differences and similarities among major hydrogeologic settings and to evaluate whether these characteristics might be associated with groundwater methane occurrence. A comparison of well completion characteristics with methane occurrence indicated that individually, characteristics are not obviously associated. The thickness of bedrock penetrated and the elevation of the bottom of bedrock wells were plotted in relation to the four major hydrogeologic settings (fig. 8), and the thickness of confining units and the elevation of well bottoms in confined bedrock valley wells were plotted in relation to methane concentrations (fig. 8; appendix 5). The thickness of bedrock penetrated was highest in upland unconfined bedrock wells, which have the lowest methane concentrations. This indicates that the thickness of bedrock penetration (bedrock surface area) by itself is not a critical factor for methane occurrence; valley bedrock wells with much less bedrock penetration have the highest methane concentrations. The elevation of the bottom of bedrock wells in relation to major hydrogeologic setting essentially reflects topography; the lowest elevations of bedrock penetration are associated with confined valley bedrock wells. A comparison of methane concentration with confining unit thickness in valley confined settings found no obvious relation nor did a comparison of methane concentration with the elevation of the bottom of confined bedrock valley wells (appendix 5).

\section{Use of Isotopic Data to Assess Methane Source(s)}

Isotopic ratios of carbon $\left(\delta^{13} \mathrm{C}\right)$ and hydrogen $(\delta \mathrm{D})$ in methane were measured in 24 samples with at least $0.3 \mathrm{mg} / \mathrm{L}$ of methane. Results are plotted on an isotope crossplot in figure 9 with the major methane source areas: (1) microbial methane production by fermentation, (2) microbial methane production by carbon dioxide reduction, and (3) thermogenic methane production (source area extents from Révész and others, 2012). The thermogenic sub-areas characteristic of Marcellus Shale gas samples are also included for referencenortheastern Pennsylvania from Molofsky and others (2011); north-central/northeastern Pennsylvania from A. Baldassare, ECHELON Applied Geoscience Consulting, written commun., 2013; and Steuben County, N.Y., (near the western boundary of the study area) from Osborn and McIntosh (2010). The 24 samples indicate increasing thermal maturity from west to east. Arrows are included in figure 9 to indicate the direction of increasing thermal maturity and the general effect of methane oxidation on isotopic ratios (Coleman and others, 1981). Two samples are not shown in figure 9 because they plot outside of the standard crossplot scale. The sample results were re-verified by the laboratory. They were exceedingly "heavy" in $\delta \mathrm{D}\left(-6,-89\right.$ per mil) and less so in $\delta^{13} \mathrm{C}(-37.7$, -37.2 per mil). These samples may represent methane gases that have undergone substantial oxidation (Coleman and others, 1981). However, both samples were from confined valley settings and contained virtually no oxygen $(0.1 \mathrm{mg} / \mathrm{L})$.

Methane was predominantly of thermogenic origin in valley-setting samples and predominantly of microbial origin (carbon dioxide reduction) in upland-setting samples. Fourteen valley-setting samples plotted within the low-maturity end of the thermogenic source field, and two samples plotted as a mix of thermogenic and microbial sources of methane. The mixed samples had the highest methane concentrations ( 55 and $32 \mathrm{mg} / \mathrm{L}$ ) and might be interpreted as either extremely low-maturity thermogenic in some thermogenic source-area delineations (Schoell, 1980; Osborn and others, 2011) or as a mix of carbon dioxide reduction- and fermentation-sourced methane. Fermentation is most commonly associated with near-surface processes (wetlands and landfills) but has also been documented in shallow and deep groundwater flow systems (Hansen and others, 2001; Veto and others, 2004). Three of four upland-setting methane samples plotted within or on the boundary of the microbial (carbon dioxide reduction) field (fig. 9). The fourth upland-setting sample and one valleyconfined setting sample with low methane concentrations ( 0.34 and $0.38 \mathrm{mg} / \mathrm{L}$, respectively; fig. 9 ) have less negative $\delta \mathrm{D}$ than the other microbial- or thermogenic-sourced samples, which may indicate that some degree of microbial oxidation of methane has altered the isotopic ratios (Coleman and others, 1981). No samples plotted within the thermogenically mature Marcellus Shale gas-source areas for northeastern or northcentral Pennsylvania (fig. 9), and all samples were characterized by $\delta^{13} \mathrm{C}$ ratios of less than -40 per mil.

The samples that plot within or near the microbial carbon dioxide reduction source field were from upland settings (three confined, one of uncertain confinement) and were widely spaced across the study area. The association is notable because no upland methane samples plotted within the thermogenic source area. The only other sample within the carbon dioxide reduction source field was from a valley confined bedrock setting. Methane derived from this microbial pathway has been documented in many settings, such as glacial sediments and Paleozoic bedrock in Illinois (Coleman and others, 1988) and organic-rich shales in Michigan (Martini and others, 1996). Similar microbial gas has been identified south and west of the study area in north-central Pennsylvania (Révész and others, 2012). Spatial trends (geographically north-south or east-west) of isotopic signatures are not evident across the study area. 

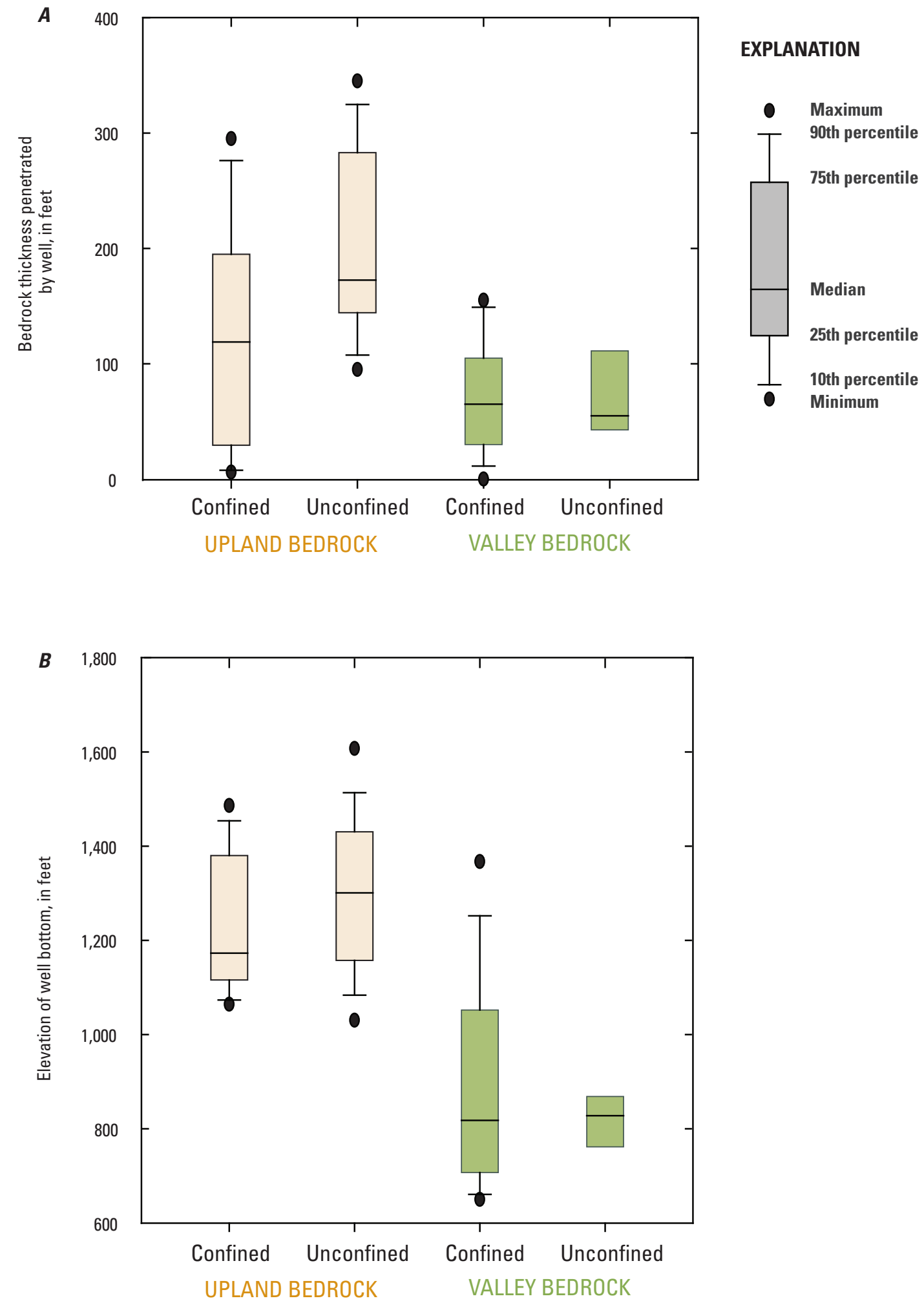

Figure 8. Distribution of characteristics of wells completed in bedrock hydrogeologic settings in southcentral New York: $A$, Bedrock thickness penetrated by wells and $B$, elevations of the bottom of bedrock wells. 


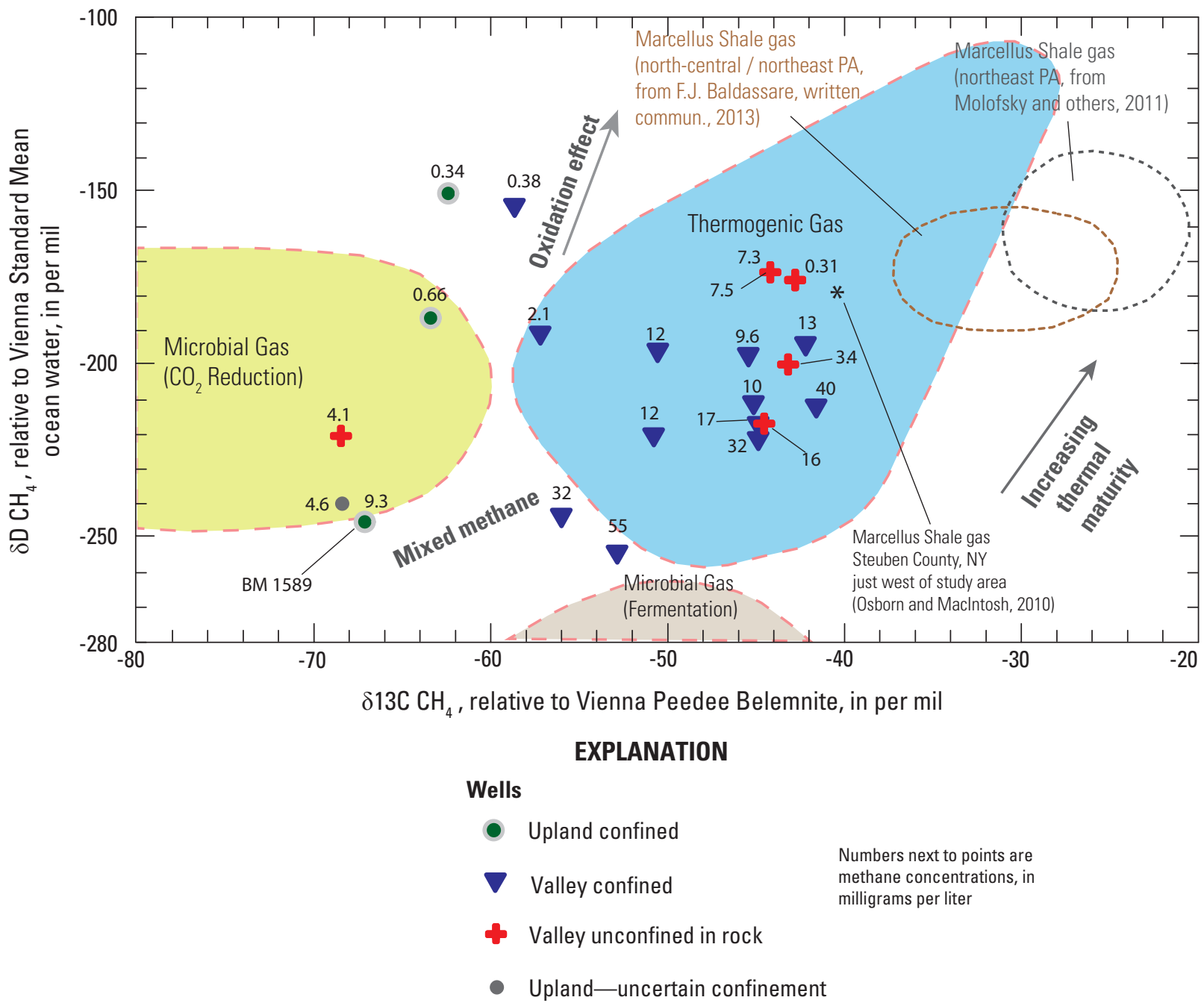

Figure 9. Stable-isotopic composition of carbon (C) and hydrogen (deuterium; D) in methane $\left(\mathrm{CH}_{4}\right)$ in water-well samples from south-central New York. Methane isotope ratio source fields from Révész and others (2012), unless noted otherwise. Number next to each point is methane concentration, in milligrams per liter.

\section{Conceptual Model of Methane Occurrence in South-Central New York}

The differences in groundwater methane occurrence among the hydrogeologic setting classes (table 3 ) indicate that this classification system provides a basis for understanding where groundwater methane (in wells) may be present at quantities greater than trace concentrations. Settings with at least one methane detection greater than or equal to 0.1 or $5 \mathrm{mg} / \mathrm{L}$ (tables $3 \mathrm{~A}-\mathrm{B}$ ) include all valley settings, except unconfined sand and gravel, and the upland confined bedrock setting. Methane concentrations greater than or equal to $10 \mathrm{mg} / \mathrm{L}$ (table 3C) are exclusively found in valley settingsunconfined or confined bedrock and confined sand and gravel. Concentrations greater than or equal to $28 \mathrm{mg} / \mathrm{L}$ were present only in samples from confined bedrock within valleys. These settings are discussed below within the context of groundwater flow, basic chemistry (field characteristics), and methane isotopic data and are illustrated conceptually in figure 10, a schematic hydrogeologic section. This conceptualization of methane occurrence is based on a limited dataset and, as such, is considered preliminary and may be subject to testing as additional data are collected in the region.

The methane concentration and isotopic data can be integrated with hydrogeologic setting, basic chemistry, understanding of groundwater flow systems, and wellboreflow conditions to explain methane occurrence in the groundwater from domestic wells in south-central New York (fig. 10). Widespread occurrence of thermogenic methane in bedrock wells in valley areas likely results from the close vertical proximity to underlying methane-bearing transitional 


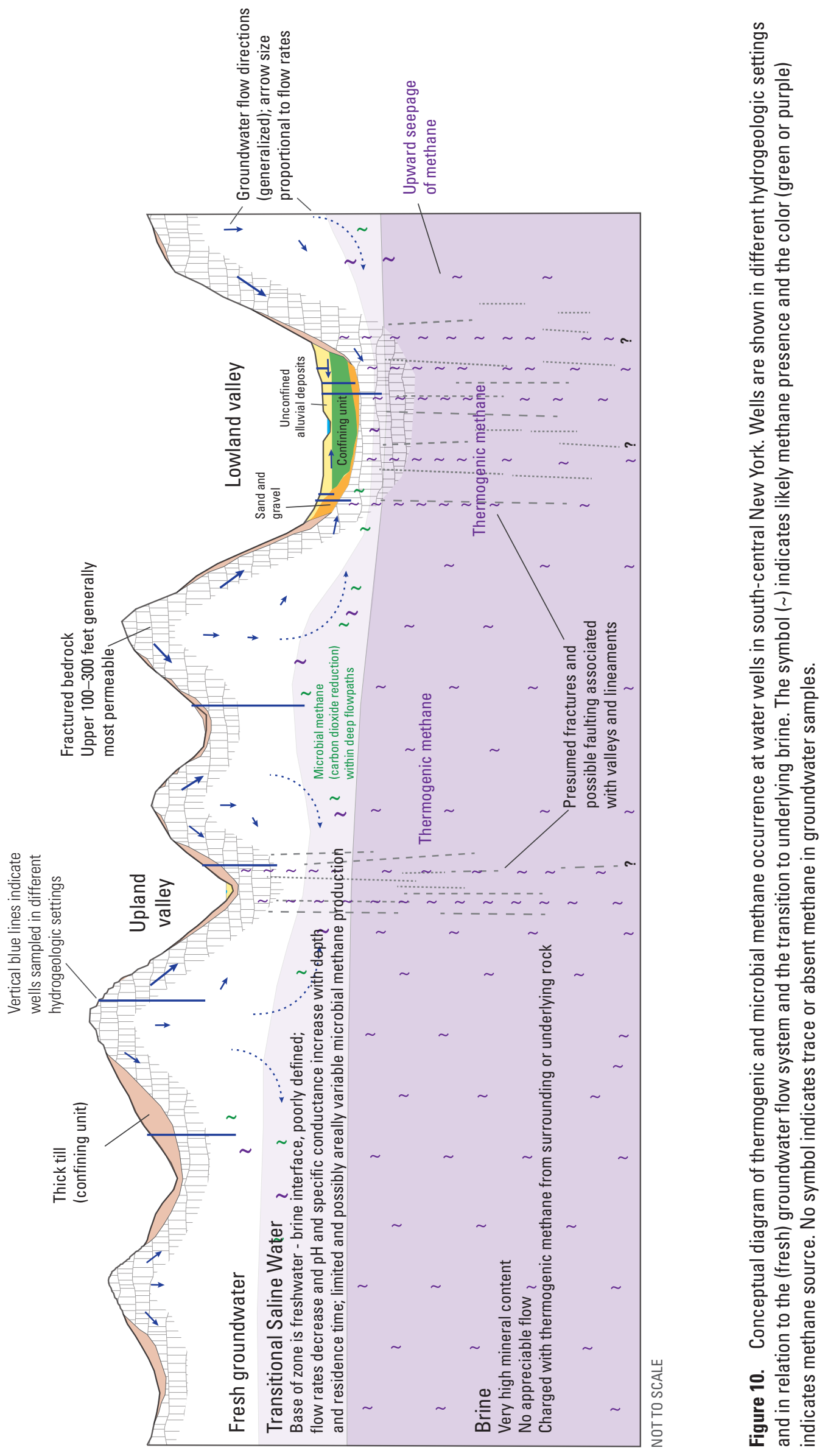


saline groundwater and brine and possible enhanced fracture permeability, whereas the limited occurrence in confined bedrock of upland areas results from a microbial source (carbon dioxide reduction) that represents highly reducing groundwater conditions within deeper, slow groundwater flow paths of the subregional flow system. Some waters from upland wells with low methane concentrations may represent a mixture of microbial and thermogenic methane. The convergence of groundwater discharge in valley areas results in some valley-area methane samples with a microbial source or possibly a mix of methane sources (predominantly thermogenic). Within this framework, confinement appears to enhance the accumulation of methane.

Valleys and uplands.-The strong association of methane (and more saline groundwater) from wells in valley settings is consistent with historical information (Williams, 2010) and with the results of Molofsky and others $(2011,2013)$ and Warner and others (2012). Methane at concentrations of concern [greater than or equal to $10 \mathrm{mg} / \mathrm{L}$; U.S. Office of Surface Mining recommendation in Eltschlager and others (2001)] were exclusively from wells within the valley settings; of the 17 samples with at least $1 \mathrm{mg} / \mathrm{L}$ of methane, all but one were from a valley setting.

In large (lowland) valleys, freshwater flow systems are generally thin (fig. 10), and thus, wells are in close proximity to underlying transitional saline water and deeper brine, which are likely charged with methane, that is representative of the either local bedrock or the upward methane seepage rate from underlying source rock (fig. 10). Methane associated with most brines in the region is likely of thermogenic origin, as indicated by methane isotopic data from natural gas samples from underlying strata (Osborn and others, 2011; Molofsky and others, 2011). Groundwater samples with elevated methane (above background levels) in these valleys have high $\mathrm{pH}$ (typically greater than 7.7) and specific conductance (greater than about $770 \mu \mathrm{S} / \mathrm{cm}$ at $25^{\circ} \mathrm{C}$ ) that reflect long groundwater residence times and likely some mixing with, or diffusion from, residual saline water or brine in bedrock incompletely flushed by freshwater circulation (fig. 10). In south-central New York, Williams (2010) documents thin freshwater zones beneath valleys and thicker freshwater zones in uplands. Also most methane and saltwater occurrences reported in that study were in wells in valleys. The saline spring water at Salt Spring State Park in Pennsylvania (south of the study area) is charged with methane (Molofsky and others, 2011) and represents a mixture of freshwater and less than 7 percent brine (Warner and others, 2012). Sampling of a deep corehole in an upland setting in north-central Pennsylvania indicates the presence of elevated methane of thermogenic origin associated with saline-water or brinebearing fractures starting at $915 \mathrm{ft}$ below land surface (at least $30,000 \mu \mathrm{S} / \mathrm{cm}$ at $25^{\circ} \mathrm{C}$; Risser and others, 2013).

The association of valleys with high methane concentrations and a thermogenic source is consistent with the concept that greater fracture permeability of bedrock underlying these areas provides enhancement of upward seepage of methane. Valleys exist because of some inherent weakness in bedrock; valley orientation commonly reflects some combination of the direction of glacial ice advance and regional joint, lineament, or fault orientations. Jacobi (2002) reports that field inspection of lineaments combined with analysis of subsurface data indicate that many are deepseated faults that may extend through the entire sedimentary sequence into the basement rock (fig. 1). The depth to which the faulting might affect bedrock fracture permeability is not known, but enhanced permeability to even a relatively shallow depth would be a contributing factor for increased upward seepage of methane.

The upward hydraulic-head gradients within valleys, which are areas of discharge, trend in the same direction as seepage of methane; at a minimum, upward groundwater flow would not be an impediment to upward methane seepage. Enhanced methane seepage in fractured bedrock beneath valleys is consistent with the presence of methane in both confined and unconfined valley wells that are completed in bedrock. Also, upland confined valley settings at elevations of greater than $1,100 \mathrm{ft}$ and confined by till were nearly as favorable for thermogenic methane accumulation as lowland confined valley settings (table 3 ) but were characterized by mostly low specific conductances. This is conceptually consistent with enhanced fracture permeability that allows upward seepage of dissolved gases such as methane, but not the saline water. The vertical distance of wells above transitional saline water and underlying brine (fig. 10) appears to be greater in upland valleys than in lowland valleys.

Methane in many samples from valley-area wells is thermogenically sourced, but one sample indicates a microbial source. Also, two samples with methane below the lowmaturity end of the thermogenic field may represent mixing of thermogenic and microbial methane (fig. 9). These samples could indicate that old groundwater from the subregional flow system (from the surrounding uplands) with microbially sourced methane has mixed with upward seepage of thermogenic methane from beneath valleys. Uplands presumably consist of more competent, less fractured rock than valleys, and unconfined wells completed in these areas penetrate the greatest thicknesses of bedrock (figs. 8, 10); despite the large thickness of penetrated bedrock, methane concentrations are at trace levels or absent. One reason for this observation is that the predominant groundwater flow direction in unconfined uplands (recharge areas) is downward and downslope. This relatively fast flow would act to entrain and remove upwardly seeping methane. Just as importantly, a characteristic of wells drilled in such areas is the rapid initiation of downward flow within the wellbore itself when more than one producing fracture is intersected by the wellbore (Heisig, 1999; with well logs in Heisig and Knutson, 1997) and regionwide drilling reports of losses in hydraulic head (decreasing water levels) during drilling of wells in hillside and hilltop areas. Thus, under non-pumping conditions, ambient downward flow in wellbores acts to flush the wells with relatively recent, oxygenated recharge water. These downward flow rates (fraction of a gallon to gallons per minute, depending on fracture permeability and hydraulic-head differences) seem 
likely to greatly exceed any upward seepage rate of methane. Coleman and others (1988) describe groundwater flow as the primary mechanism of microbial gas movement in Illinois groundwater; presumably, downward flowing, methane-free groundwater in the study area may overcome upward seepage of methane from underlying sources. The accelerated downward flow of oxygenated water in wellbores also results in the introduction of this water into bedrock fractures in what may have originally been a reducing groundwater environment. The introduction of oxygenated water in this environment and subsequent microbial oxidation of methane may also account for two samples that plot above the carbon-dioxide reduction area (fig. 9).

Most upland wells are likely completed much farther above transitional saline water and brine than valley wells (fig. 10) and thus are likely farther removed from thermogenic methane. The shape, depth, and sharpness of the transition zone beneath uplands is largely undefined, but limited evidence points to a surface somewhere between a subdued reflection of topography and a relatively flat surface (fig. 10) at depths of greater than or equal to $300 \mathrm{ft}$ below land surface. The microbially sourced upland sample in figure 9 represents at least one point where the uppermost transition zone depth is approximated; the well (BM1589) from which the sample was collected is shown schematically in figure 10 . This well penetrated the greatest thickness of bedrock among confined upland wells (295 ft) and had the highest methane concentration $(9.3 \mathrm{mg} / \mathrm{L}), \mathrm{pH}(9.2)$, and specific conductance $\left(1,041 \mu \mathrm{S} / \mathrm{cm}\right.$ at $\left.25^{\circ} \mathrm{C}\right)$ of all upland wells sampled.

Confinement by glacial-drift deposits.-In addition to topographic position, confinement of groundwater is also associated with accumulation of methane. Eleven of the 13 samples that exceeded $5 \mathrm{mg} / \mathrm{L}$ of methane were from confined settings. Ten were from valley settings, and one was from the upland setting. Groundwater flow beneath confining units under natural conditions is typically much slower than shallow unconfined flow that discharges to surface water or flows down high-gradient hillslopes because discharge has to pass through or circumvent the confining unit. This older, confined groundwater is characterized by relatively high $\mathrm{pH}$ where methane is present at greater than $0.1 \mathrm{mg} / \mathrm{L}$, with few exceptions (fig. 7).

Specific-conductance values in confined settings appear to indicate perhaps two scenarios of methane occurrence under confined conditions. In the first scenario, high specificconductance values (from about 750 to $2,405 \mu \mathrm{S} / \mathrm{cm}$ at $25^{\circ} \mathrm{C}$; fig. 7) in both upland and valley confined settings correspond to methane concentrations greater than $0.1 \mathrm{mg} / \mathrm{L}$. The high specific-conductance values are interpreted as representing mostly fresh groundwaters slowly circulating through bedrock that have been incompletely flushed of saline water or perhaps mixing within the wellbore of freshwater and a saline water from a fracture near the bottom of the wellbore. As discussed above, this underlying saline water is interpreted as containing elevated dissolved methane.
The second scenario consists of elevated methane in groundwater with lower specific conductance (about 400$700 \mu \mathrm{S} / \mathrm{cm}$ at $25^{\circ} \mathrm{C}$ ). This indicates upward methane seepage, separate from underlying transitional saline water or brine and accumulation within the confined setting (fig. 10). The upland confined valley settings are an example of this scenario (for example, see well TI 660 data; appendixes 1 and 4).

The lack of elevated methane in unconfined valley sand and gravel settings is consistent with relatively fast groundwater movement towards discharge points at surfacewater bodies (limited time for accumulation), the lack of a seal to trap the methane before it dissipates to the atmosphere, and elevated dissolved oxygen concentrations that support removal of methane by microbial oxidation. Three of the samples within this group represented sand-and-gravel wells completed above a confining unit over bedrock, which is probably the setting least likely in which to find methane because upward seepage from bedrock is sealed below by the intervening confining unit.

\section{Limitations of Data}

The results of this study, based on water samples collected from 66 wells in the 1,810- $\mathrm{mi}^{2}$ study area, provide a preliminary understanding of methane occurrence in groundwater of south-central New York, which could be tested with subsequent data collected in the region. The distribution of groundwater methane reported here is representative of the depth range of typical water-supply wells in the study area but may not be representative of other depths in the groundwater flow system (fig. 10). For example, one can envision atypical (unusually deep) upland wells intersecting old groundwater with much higher methane concentrations (perhaps of thermogenic origin) and higher specific-conductance values than those reported here.

The study design focused on a subset of wells that excluded wells within $1 \mathrm{mi}$ of gas wells (active or abandoned) and wells that could not be classified with some certainty. The wells not classified include those on the walls of most major valleys (initially uncertain topographic position) and upland wells with overburden between about 30 and $45 \mathrm{ft}$ (uncertain confinement).

The results of this study represent a snapshot of methane concentrations representative of a relatively dry summer period. As a dissolved gas, methane concentrations may be affected by changes in pressure, such as seasonal groundwaterlevel variations, atmospheric-pressure fluctuations, and pumping cycles of the well or the pressure tank system. Thus, different methane results from different sampling conditions are possible, and the study results may be on the high end of likely annual variation because of low groundwater levels during the summer sampling period.

Domestic plumbing systems with pressure tanks may allow some degree of gas diffusion and, thereby, affect 
measured concentrations. Sample-collection method (bottle or bag, bottle size) may also affect measured methane concentrations.

The interpretations presented here are somewhat limited by the extent of chemical analysis available for this study. Complete chemical and isotopic analyses of water samples can provide additional evidence of mixing, relative groundwater age (groundwater evolution along flow paths), and methane source. Isotopic analysis of hydrogen $(\delta \mathrm{D})$ in the water molecule and carbon $\left(\delta^{13} \mathrm{C}\right)$ in dissolved inorganic carbon in water samples can provide additional evidence for interpretation of methane sources (Révész and others, 2012, for example).

\section{Data Needs}

The interpretation of methane occurrence presented here can be used as a framework for assessing reports of stray gas, but additional methane isotopic data from upland wells are needed to verify the microbial source of methane in this part of the flow system. Lineaments, fractures, and faults, such as identified in Jacobi (2002), were not evaluated as part of this sample survey beyond the assumed association with valleys. Regional lineaments also cross upland areas, and many have been verified as faults by Jacobi (2002). Fountain and Jacobi (2002) identified some faults by methane detection in overlying soils, so that it is possible that some upland areas may have methane greater than trace levels that may be of thermogenic rather than microbial origin. A methane survey along an identified fault or fracture intensification domain (a linear strike-defined trend of closely spaced fractures, Jacobi, 2002) could be tested for potentially elevated methane across upland areas.

Subsurface data on the depth of the fresh groundwater and the nature of the transition to saline water and brine along with geochemical data, including data on dissolved gases, are needed across upland and valley areas. A future cost-effective approach could involve data collection during the early phase of any gas-well drilling.

\section{Significance of Findings}

This study advances the regional understanding of methane occurrence in south-central New York State by utilizing detailed hydrogeology (in a glaciated region) and the specifics of well completion. The study confirms the association of valley settings with methane occurrence shown by Molosfsky and others (2011) in northeastern Pennsylvania and identifies specific hydrogeologic characteristics (confinement, completion of unconfined valley wells in bedrock) within which groundwater is likely to contain methane greater than trace levels. Methane isotopic data indicate that methane of thermogenic origin is typically predominant in well water from valley areas and that limited and lower concentrations of methane in upland area wells are of either microbial origin (primarily carbon dioxide reduction) or a mix of microbial and thermogenic origin. The occurrence of thermogenic methane in valleys is interpreted as the upward seepage of dissolved gas, likely due to their close vertical proximity to underlying methane-bearing saline groundwater and brine and possibly through enhanced fracture permeability in bedrock. Methane of microbial origin is generated within the subregional flow system as groundwater becomes progressively more reducing. This methane may mix with thermogenic methane as groundwater flow converges toward valleys.

The association of methane with older groundwater (high $\mathrm{pH}$, high specific conductance) is made, and a conceptual diagram of methane occurrence is presented from interpretation of these results, field-characteristic measurements, previous work, and an understanding of groundwater flow systems in the northern Appalachian Basin.

From a practical perspective, this understanding of methane occurrence and origin provides water-resource managers and the public with a frame of reference for initial evaluation of future questions related to stray gas, particularly if high-volume hydraulic fracturing development of shale gas proceeds in New York State. For example, upland unconfined wells and valley unconfined sand and gravel wells were characterized by trace methane concentrations; therefore, reports of elevated methane in such settings would be considered unusual and not expected to occur naturally. Reports of elevated methane in valley wells that are confined and completed in bedrock would not be unusual given the sampling results from this study (2012). The difference in methane origin between upland and valley areas, as indicated by the isotopic characterization presented here, may represent a useful tool for putting methane occurrence in context. The results of this study are from a relatively small population of water-well samples and are thus subject to future refinement as additional data are collected in the region.

Groundwater methane occurrence and origins identified in this study are consistent with regional results for New York and northeast Pennsylvania. Kappel and Nystrom (2012) report that within New York State, groundwater methane (greater than $0.001 \mathrm{mg} / \mathrm{L}$ ) most frequently has occurred within sedimentary bedrock and specifically was present in 74 to 77 percent of samples from Middle Ordovician to Upper Devonian-age bedrock with associated black shales; in the present study, methane was detected at greater than $0.001 \mathrm{mg} / \mathrm{L}$ in 77 percent of bedrock groundwater samples. The low-maturity thermogenic origin indicated for many of the samples in this study has also been indicated for samples from northeast and north-central Pennsylvania (Révész and others, 2012; D.W. Risser, U.S. Geological Survey, written commun., 2013; Molofsky and others, 2011; Osborn and others, 2011), across central New York in southeastern Chenango County (R. Nyahay, independent consultant, written commun., 2012), and south-central Delaware County to as far east as Saratoga County, New York (W.M. Kappel, U.S. Geological Survey, written commun., 2012). Microbial (carbon dioxide reduction) and mixed-origin methane identified in this study were also identified in north-central Pennsylvania (Révész and others, 2012). 


\section{Summary and Conclusions}

A 66-well survey of methane occurrence in groundwater was carried out during the summer of 2012 to address a lack of information for south-central New York. The study area encompasses about 1,810 square miles and includes all or part of Broome, Tioga, Chemung, Chenango, and Delaware Counties. Water wells within a 1-mile radius of known gas wells (active, exploratory, or abandoned) were excluded from the survey. The well-selection approach focused on hydrogeologic characteristics of the area that might affect accumulation of methane from either in situ generation or upward seepage from underlying source rock. The classification included topographic position (valley and upland, which relates to position within the groundwater flow system), confinement or non-confinement of groundwater by glacial-drift deposits, well completion characteristics, and local geologic characteristics.

The selection criteria for wells for sampling required well-construction and well-log data for subsequent classification. Valley and upland settings were defined by generating a synthetic stream network from elevation data using criteria for the start of streams that omitted small upland streams. A maximum slope criterion was used to further pare down the network. The widths of valleys were defined as the area within 75 feet elevation above the local stream, but valleys were locally edited to (1) remove small streams with significant reaches within large valleys, (2) increase valley widths to regular valley wall contours in valley segments choked with glacial deposits that had been deeply incised by the valley stream or river or (3) truncate headwater streams in relatively flat (high plateau) upland areas with little stream incision (small local relief).

Field characteristics ( $\mathrm{pH}$, specific conductance, dissolved oxygen, and temperature) were measured at each well, and samples were collected and analyzed for dissolved gases, including methane and lower-chain hydrocarbons. Carbon and hydrogen isotopic ratios of methane were measured in 24 samples with at least 0.3 milligrams per liter $(\mathrm{mg} / \mathrm{L})$ of methane.

Results of sampling indicate that occurrence of methane in groundwater in the region is common (greater than or equal to $0.1 \mathrm{mg} / \mathrm{L}$ in 35 percent of samples) but is associated with specific hydrogeologic settings. Wells completed in bedrock within valleys and with confined groundwater conditions were most closely associated with methane occurrence. Fifty-seven percent of valley wells had greater than or equal to $0.1 \mathrm{mg} / \mathrm{L}$ methane, whereas only 10 percent of upland wells equaled or exceeded that value. Isotopic signatures differed between these groups as well. Methane in valley wells was predominantly thermogenic in origin, likely due to close vertical proximity to underlying methane-bearing saline groundwater and brine and possibly from enhanced bedrock-fracture permeability beneath valleys that provides an avenue for upward seepage of dissolved methane. Isotopic signatures of the few upland well samples with sufficient methane indicated a microbial origin (carbon dioxide reduction) or microbially produced methane that had undergone mixing with thermogenic methane, or oxidation. Most upland wells are likely completed much farther above transitional saline water and brine than valley wells (fig. 10) and thus likely are farther removed from thermogenic methane. The microbial methane is interpreted as being produced by bacteria that utilize carbon dioxide or formational organic matter in highly reducing environments within the subregional groundwater flow system. This methane is entrained with groundwater flow, whereas thermogenic methane in valley areas largely implies upward seepage of dissolved gas and not saline water chemistry. This characterization of groundwater methane provides a conceptual framework that can be utilized in investigation of stray gas in southcentral New York, and the understanding of methane occurrence can be refined as additional data are collected.

\section{References Cited}

Busenberg, E., Plummer, L.N., Bartholomay, R.C., and Wayland, J.E., 1998, Chlorofluorocarbons, sulfur hexafluoride, and dissolved permanent gases in ground water from selected sites in and near the Idaho National Engineering and Environmental Laboratory, Idaho, 199497: U.S. Geological Survey Open-File Report 98-274, 72 p.

Cadwell, D.H., and Dineen, R.J., 1987, Surficial geologic map of New York-Hudson-Mohawk Sheet: New York State Museum Geological Survey, Map and Chart Series no. 40, 1:250,000.

Chafin, D.T., 1994, Sources and migration pathways of natural gas in near-surface ground water beneath the Animas River Valley, Colorado and New Mexico: U.S. Geological Survey Water-Resources Investigations Report 94-4006, 56 p.

Coates, D.R., 1966, Glaciated Appalachian Plateau - till shadows on hills: Science, v. 152, p. 1617-1619.

Coleman, D.D., Liu, Chao-Li, and Riley, K.M., 1988, Microbial methane in the shallow Paleozoic sediments and glacial deposits of Illinois, U.S.A.: Chemical Geology, v. 71, p. $23-40$.

Coleman, D.D., Risatti, J.B., and Schoell, Martin, 1981, Fractioantion of carbon and hydrogen isotopes by methaneoxidizing bacteria: Geochimica et Cosmochimica Acta, v. 45 , p. $1033-1037$.

Coleman, J.L., Milici, R.C., Cook, T.A., Charpentier, R.R., Kirshbaum, M.A., Klett, T.R., Pollastro, R.M., and Schenk, C.J., 2011, Assessment of undiscovered oil and gas resources of the devonian marcellus shale of the appalachian basin province, 2011: U.S. Geological Survey Fact Sheet 2011-3092, 2 p., http://pubs.usgs.gov/fs/2011/3092/. 
Direct Geochemical, 2004, Application of specialized surface geochemical testing to define productive and faulted areas related to hydrothermal dolomite gas production in the Appalachian Basin of New York: Contract Agreement 8168: New York State Energy Research and Development Authority, $19 \mathrm{p}$.

Eltschlager, K.K., Hawkins, J.W., Ehler, W.C., and Baldassare, Fred, 2001, Technical measures for the investigation and mitigation of fugitive methane hazards in areas of coal mining: U.S. Department of the Interior, Office of Surface Mining Reclamation and Enforcement, 125 p., accessed January 9, 2012, at http://www. techtransfer.osmre.gov/ NTTMainSite/Library/hbmanual/ methane/methane.pdf.

Fisher, D.W., Isachsen, Y.W., and Rickard, L.V., 1970, Geologic map of New York, Hudson-Mohawk sheet: New York State Museum and Science Service, Map and Chart Series no. 15, 1:250,000.

Fountain, J.C., and Jacobi, R.D., 2000, Detection of buried faults and fractures using soil gas analysis: Environmental and Engineering Geoscience, v. VI, no. 3, p. 201-208.

Hansen, L.K., Jakobsen, Rasmus, and Postma, Dieke, 2001, Methanogenesis in a shallow sandy aquifer, Romo, Denmark: Geochimica et Cosmochimica Acta, v. 65, no. 17, p. 2925-2935.

Heisig, P.M., 1999, Water resources of the Batavia Kill basin at Windham, Greene County, New York: U.S. Geological Survey Water-Resources Investigations Report 98-4036, $96 \mathrm{p}$.

Heisig, P.M., 2012, Hydrogeology of the Susquehanna River valley-fill aquifer system and adjacent areas in eastern Broome and southeastern Chenango Counties, New York: U.S. Geological Survey Scientific Investigations Report 2012-5282, 21 p., 1 pl.

Heisig, P.M., and Knutson, K.D., 1997, Borehole geophysical data from bedrock wells at Windham, New York: U.S. Geological Survey Open-File Report 97-42, 24 p.

Helsel, D.R., and Hirsch, R.M., 2002, Statistical methods in water resources: U.S. Geological Survey Techniques of Water Resources Investigations, book 4, chap. A3, 522 p.

Holecek, T.J., Randall, A.D., Belli, J.L., and Allen, R.V., 1982, Geohydrology of the valley-fill aquifer in the EndicottJohnson City area, Broome County, New York: U.S. Geological Survey Open-File Report 82-268, 5 sheets, scale 1:24,000.

Hopkins, H.T., 1966, The fresh-saline water interface in Kentucky: Kentucky Geological Survey Report, 19 p., 1 pl.

Isotech Laboratories, Inc., 2012, Instrumentation, accessed January 6, 2012, at http://isotechlabs.com/.
Jacobi, R.D., 2002, Basement faults and seismicity in the Appalachian Basin of New York State: Tectonophysics, v. 353 , p. $75-113$.

Kappel, W.M., and Nystrom, E.A., 2012, Dissolved methane in New York groundwater, 1999-2011: U.S. Geological Survey Open-File Report 2012-1162, 6 p., http://pubs.usgs. gov/of/2012/1162.

Kipp, J.A., Lawrence, F.W., and Dinger, J.S., 1983, A conceptual model of ground-water flow in the Eastern Kentucky Coalfield, in Graves, D.H., ed., Symposium on Surface Mining, Hydrology, Sedimentology, and Reclamation: Lexington, Ky., University of Kentucky, November 27-December 2, 1983, p. 543-548.

Kirschbaum, M.A., Schenk, C.J., Cook, T.A., Ryder, R.T., Charpentier, R.R., Klett, T.R., Gaswirth, S.B., Tennyson, M.E., and Whidden, K.J., 2012, Assessment of undiscovered oil and gas resources of the Ordovician Utica Shale of the Appalachian Basin Province, 2012: U.S. Geological Survey Fact Sheet 2012-3116, 6 p., http://pubs.usgs.gov/ fs $/ 2012 / 3116 /$.

MacNish, R.D., and Randall, A.D., 1982, Stratified-drift aquifers in the Susquehanna River basin, New York: New York State Department of Environmental Conservation Bulletin $75,68 \mathrm{p}$.

Martini, A.M., Budai, J.M., Walter, L.M., and Schoell, Martin, 1996, Microbial generation of economic accumulations of methane within a shallow organic-rich shale: Nature, v. 383, p. $155-158$.

Miller, T.S., and Pitman, L.J., 2012, Hydrogeology of the stratified-drift aquifers in the Cayuta Creek and Catatonk Creek valleys in parts of Tompkins, Schuyler, Chemung, and Tioga Counties, New York: U.S. Geological Survey Scientific Investigations Report 2012-5127, 44 p., 3 pls.

Miller, T.S., Randall, A.D., Belli, J.L., and Allen, R.V., 1982, Geohydrology of the valley-fill aquifer in the Elmira area, Chemung County, New York: U.S. Geological Survey Open-File Report 82-110, 7 sheets, scale 1:24,000.

Minns, S.A., 1993, Conceptual model of local and regional flow in the Eastern Kentucky Coalfield: Kentucky Geological Survey, Thesis Series 6, Series XI, 194 p.

Molofsky, L., Connor, J., Wylie, A., and Wagner, T., 2011, Methane in Pennsylvania water wells unrelated to Marcellus shale fracturing: Oil and Gas Journal, v. 109, no. 49, 12 p., accessed January 23, 2012, at http://www.ogj.com/1/ vol-109/issue-49/exploration-development/methane-inpennsylvania-water-full.html. 
Molofsky, L., Connor, J., Wylie, A., Wagner, T., and Farhat, S.K., 2013, Evaluation of methane sources in groundwater in northeastern Pennsylvania: Groundwater, v. 51, no. 3, p. 333-349.

Muller, E.H., and Cadwell, D.H., 1986, Surficial geologic map of New York - Finger Lakes Sheet: New York State Museum-Geological Survey, Map and Chart Series no. 40, scale $1: 250,000$.

New York State Museum Reservoir Characterization Group, 2009, Schematic north-south cross section Finger Lakes Region of New York State: Albany, N.Y., New York State Museum Reservoir Characterization Group.

Nystrom, E.A., 2012, Groundwater quality in the Delaware and St. Lawrence River Basins, New York, 2010: U.S. Geological Survey Open-File Report 2011-1320, 58 p., http://pubs. usgs.gov/of/2011/1320/.

Osborn, S.G., Avner, Vengosh, Warner, N.R., and Jackson, R.B., 2011, Methane contamination of drinking water accompanying gas-well drilling and hydraulic fracturing: Proceedings of the National Academy of Sciences, http://www.pnas.org/cgi/doi/10.1073/pnas.1100682108, $5 \mathrm{p}$.

Osborn, S.G., and McIntosh, J.C., 2010, Chemical and isotopic tracers of the contribution of microbial gas in Devonian organic-rich shales and reservoir sandstones, northern Appalachain Basin: Applied Geochemistry, v. 25, p. $456-471$.

Poth, C.W., 1962, The occurrence of brine in western Pennsylvania: Pennsylvania Topographic and Geologic Survey Bulletin M 47, 53 p.

Poth, C.W., 1963, Geology and hydrology of the Mercer Quadrangle, Mercer, Lawrence, and Butler Counties, Pennsylvania: Pennsylvania Topographic and Geologic Survey Water Resources Report 16, 149 p.

Randall, A.D., 1972, Records of wells and test borings in the Susquehanna River basin, New York: New York State Department of Environmental Conservation Bulletin 69, $92 \mathrm{p}$.

Randall, A.D., 2001, Hydrogeologic framework of stratifieddrift aquifers in the glaciated northeastern United States: U.S. Geological Survey Professional Paper 1415-B, 179 p., $1 \mathrm{pl}$.

Révész, K.M., Breen, K.J., Baldassare, A.J., and Burruss, R.C., 2012, Carbon and hydrogen isotopic evidence for the origin of combustible gases in water-supply wells in north-central Pennsylvania: Applied Geochemistry, v. 27, p. 361-375.
Reynolds, R.J., 2003, Hydrogeology of the Waverly-Sayre area in Tioga and Chemung Counties, New York and Bradford County, Pennsylvania: U.S. Geological Survey Open-File Report 02-284, 6 sheets, scale 1:24,000, 1 CD-ROM.

Reynolds, R.J., and Garry, J.D., 1990, Hydrogeology of the valley-fill aquifer at Owego, Tioga County, New York: U.S. Geological Survey Water-Resources Investigations Report 89-4000, 8 sheets, scale 1:24,000.

Rickard, L.V., and Fisher, D.W., 1970, Geologic map of New York, Finger Lakes sheet: New York State Museum and Science Service, Map and Chart Series no. 15, 1:250,000.

Risser, D.W., Williams, J.H., Hand, K.L., Behr, Rose-Anna, and Markowski, A.K., 2013, Geohydrologic and waterquality characterization of a fractured-bedrock test hole in an area of Marcellus Shale gas development, Bradford County, Pennsylvania: Pennsylvania Geological Survey, 4th ser., Open-File Miscellaneous Report OFMI 13-01.0, $48 \mathrm{p}$.

Schiner, G.R., and Gallaher, J.T., 1979, Geology and groundwater resources of western Crawford County, Pennsylvania: Pennsylvania Geological Survey Water Resource Report 46, $50 \mathrm{p}$.

Schoell, Martin, 1980, The hydrogen and carbon isotopic composition of methane from natural gases of various origins: Geochimica et Cosmochimica Acta, v. 44, p. 649-661.

U.S. Geological Survey, variously dated, National field manual for the collection of water-quality data: U.S. Geological Survey Techniques of Water-Resources Investigations, book 9, chaps. A1-A9, http://pubs.water.usgs.gov/twri9A.

Veto, Istvan, Futo, Istvan, Horvath, Istvan, and Szanto, Zsuzsa, 2004, Late and deep fermentive methanogenesis as reflected in the H-C-O-S isotopy of the methane-water system in deep aquifers of the Pannonian Basin (SE Hungary): Organic Geochemistry, v. 35, p. 713-723.

Warner, N.R., Jackson, R.B., Darrah, T.H., Osborn, S.G., Down, Adrian, and Zhao, Kaiguang, 2012, Geochemical evidence for possible natural migration of Marcellus Formation brine to shallow aquifers in Pennsylvania: Proceedings of the National Academy of Sciences, v. 109, no. 30, p. 11961-11966.

Williams, J.H., 2010, Evaluation of well logs for determining the presence of freshwater, saltwater, and gas above the Marcellus Shale in Chemung, Tioga, and Broome Counties, New York: U.S. Geological Survey Scientific Investigations Report 2010-5224, 27 p., http://pubs.usgs. gov/sir/2010/5224/. 
Williams, J.W., Taylor, L.E., and Low, D.J., 1998, Hydrogeology and groundwater quality of the glaciated valleys of Bradford, Tioga, and Potter Counties, Pennsylvania: Pennsylvania Geological Survey Water Resource Report 68, $89 \mathrm{p}$.

Wrightstone, Gregory, 2009, Marcellus Shale-Geologic controls on production, adapted from extended abstract prepared for oral presentation at AAPG Annual Convention, Denver, Colorado, June 7-10, 2009, posted September 22, 2009, http://www.searchanddiscovery.com/documents/ 2009/10206wrightstone/.

Wunsch, D.R., 1993, Ground-water geochemistry and its relationship to the flow system at an unmined site in the Eastern Kentucky Coal Field: Kentucky Geological Survey, Thesis Series 5, Series XI, 128 p. 
THIS PAGE INTENTIONALLY LEFT BLANK 
Appendix 1. Description of Selected Wells in SouthCentral New York, Including Hydrogeologic Setting Class, Well Completion Information, Aquifer, and Bedrock Geology

[Available separately at http://pubs.usgs.gov/sir/2013/5190/]

Appendix 2. Constituents Analyzed in, and Laboratory Methods Used for, Water Samples Collected from Selected Wells in South-Central New York

[Available separately at http://pubs.usgs.gov/sir/2013/5190/]

Appendix 3. Results of Analyses for Dissolved Gases in Water Samples Collected from Selected Water Wells in South-Central New York, 2012 (USGS CFC Laboratory)

[Available separately at http://pubs.usgs.gov/sir/2013/5190/]

Appendix 4. Results of Analyses for Physical Characteristics, and Dissolved Gases, Including Hydrocarbons and Hydrocarbon Isotopes in Water Samples Collected from Wells in South-Central New York, 2012

[Available separately at http://pubs.usgs.gov/sir/2013/5190/]

Appendix 5. Methane Concentration in Relation to $A$, Confining Unit Thickness in Bedrock Wells in Valley Settings and B, Elevation of the Bottom of Confined Bedrock Valley Wells in South-Central New York. 

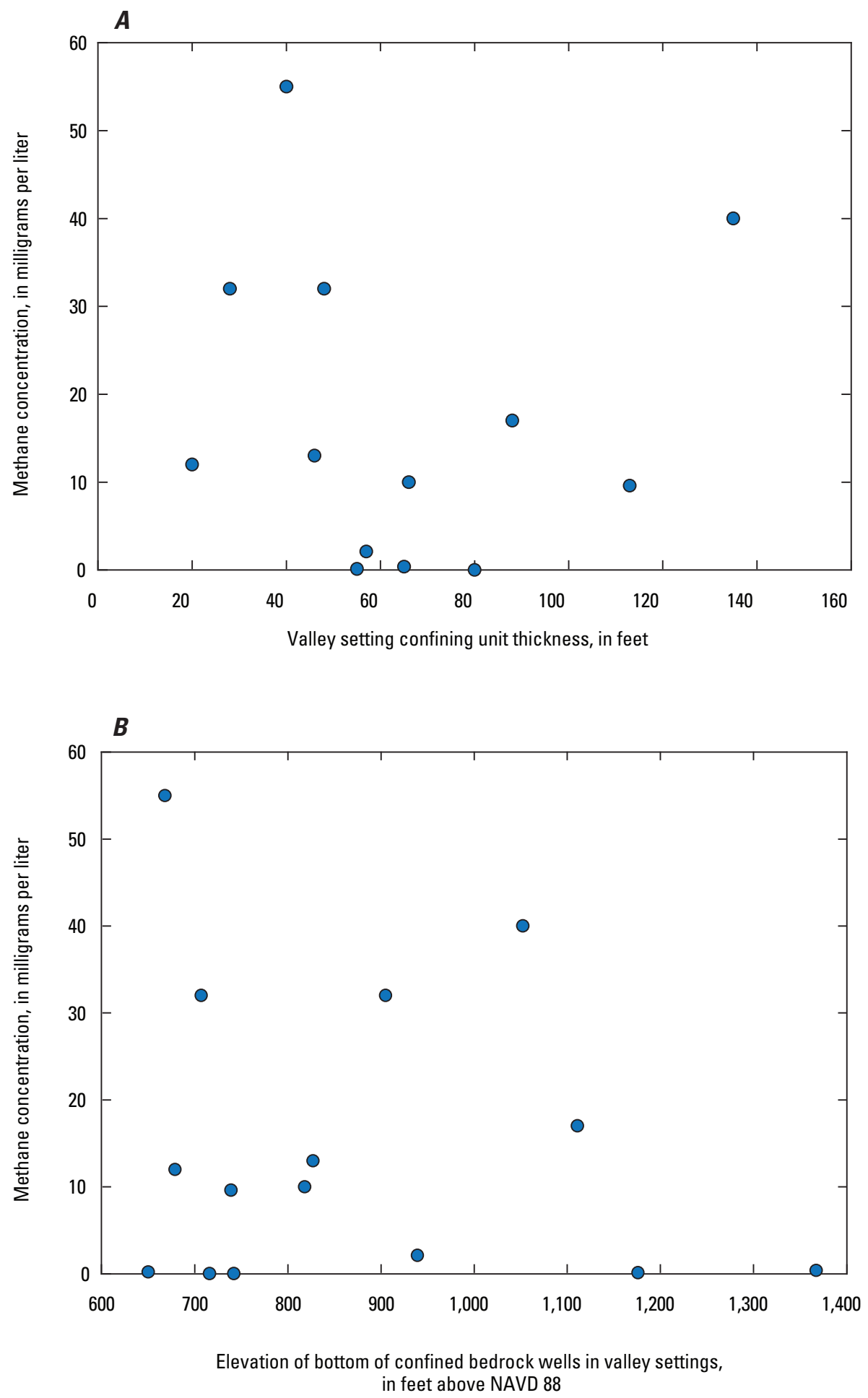

Appendix 5. Methane concentration in relation to $A$, confining unit thickness in bedrock wells in valley settings and $B$, elevation of the bottom of confined bedrock valley wells in south-central New York. 
Prepared by the Pembroke and West Trenton Publishing Service Centers.

For more information concerning this report, contact:

Director

U.S. Geological Survey

New York Water Science Center

425 Jordan Road

Troy, NY 12180-8349

dc_ny@usgs.gov

or visit our Web site at:

http://ny.water.usgs.gov 


\section{$\frac{\mathbb{3}}{3}$}

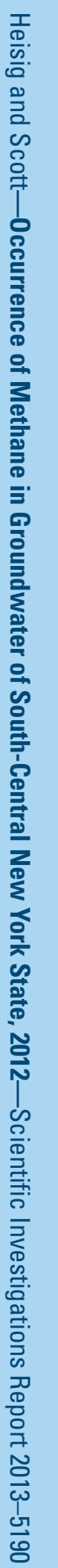

